\title{
International Perspectives on the Legal Environment for Selection
}

\author{
BRETT MYORS \\ Griffith University \\ FILIP LIEVENS, EVELINE \\ SCHOLLAERT, AND GREET VAN HOYE \\ Ghent University \\ STEVEN F. CRONSHAW \\ University of Northern British Columbia \\ ANTONIO MLADINIC AND \\ VIVIANA RODRÍGUEZ \\ Pontificia Universidad Católica de Chile \\ HERMAN AGUINIS \\ University of Colorado Denver \\ DIRK D. STEINER AND \\ FLORENCE ROLLAND \\ Université de Nice-Sophia Antipolis \\ HEINZ SCHULER \\ University of Hohenheim \\ ANDREAS FRINTRUP \\ HR Diagnostics \\ IOANNIS NIKOLAOU AND \\ MARIA TOMPROU \\ Athens University of Economics and \\ Business \\ S. SUBRAMONY AND \\ SHABU B. RAJ \\ Defence Institute of Psychological \\ Research \\ SHAY TZAFRIR \\ University of Haifa \\ PETER BAMBERGER \\ Technion-Israel Institute of Technology \\ MARILENA BERTOLINO \\ University of Trento \\ MARCO MARIANI \\ University of Bologna
}

FRANCO FRACCAROLI

University of Trento

TOMOKI SEKIGUCHI

Osaka University

BETTY ONYURA

University of Guelph

HYUCKSEUNG YANG

Yonsei University

NEIL ANDERSON AND

ARNE EVERS

University of Amsterdam

OLEKSANDR CHERNYSHENKO

University of Canterbury

PAUL ENGLERT

OPRA Consulting Group

HENNIE J. KRIEK

SHL and University of South Africa

TINA JOUBERT

$S H L$

JESÚS F. SALGADO

University of Santiago de Compostela

CORNELIUS J. KÖNIG AND

LARISSA A. THOMMEN

Universität Zürich

AICHIA CHUANG

National Taiwan University

HANDAN KEPIR SINANGIL

Marmara University

MAHMUT BAYAZIT

Sabanci University

MARK COOK

University of Wales

WINNY SHEN AND PAUL R. SACKETT

University of Minnesota 


\begin{abstract}
Perspectives from 22 countries on aspects of the legal environment for selection are presented in this article. Issues addressed include (a) whether there are racial/ethnic/religious subgroups viewed as "disadvantaged," (b) whether research documents mean differences between groups on individual difference measures relevant to job performance, (c) whether there are laws prohibiting discrimination against specific groups, (d) the evidence required to make and refute a claim of discrimination, (e) the consequences of violation of the laws, (f) whether particular selection methods are limited or banned, (g) whether preferential treatment of members of disadvantaged groups is permitted, and (h) whether the practice of industrial and organizational psychology has been affected by the legal environment.
\end{abstract}

In the United States, the legal context plays a major role in how psychologists approach selection system development. Psychologists know well the set of protected groups, the approaches to making an a priori case of discrimination (e.g., differential treatment vs. adverse impact), the key court cases influencing selection, and the prohibitions against preferential treatment (e.g., the 1991 ban on score adjustment or withingroup norming). Selection texts (e.g., Guion, 1998) and human resource management texts (e.g., Cascio \& Aguinis, 2005) give prominent treatment to the legal context.

One major theme is the growing internationalization of industrial and organiza- tional (I-O) psychology. Psychologists from all over the world contribute to our journals and to our conferences. U.S. test publishers and consulting firms establish offices all over the world. One suggestion that surfaced in considering topics for this journal was to take a broader look at the legal environment for selection, examining similarities and differences in various countries.

In response to this suggestion, the editor (Paul Sackett) prepared a set of questions about the legal environment for selection, prepared model answers describing the legal environment in the United States, and contacted psychologists in a variety of countries, asking them to prepare a document

Correspondence concerning this article should be addressed to Paul R. Sackett. E-mail: psackett@umn.edu

Address: Department of Psychology, University of Minnesota, Elliott Hall, 75 East River Road, Minneapolis, MN 55455

Brett Myors, School of Psychology, Griffith University; Filip Lievens, Eveline Schollaert, and Greet Van Hoye, Department of Personnel Management and Work Organizational Psychology, Ghent University; Steven F. Cronshaw, School of Business, University of Northern British Columbia; Antonio Mladinic and Viviana Rodríguez, Department of Psychology, Pontificia Universidad Católica de Chile; Herman Aguinis, The Business School, University of Colorado Denver; Dirk D. Steiner and Florence Rolland, Laboratoire de Psychologie Cognitive et Sociale, Université de Nice-Sophia Antipolis; Heinz Schuler, University of Hohenheim; Andreas Frintrup, HR Diagnostics; Ioannis Nikolaou and Maria Tomprou, Department of Management Science and Technology, Athens University of Economics and Business; S. Subramony and Shabu B. Raj, Defence Institute of Psychological Research; Shay Tzafrir, Department of Human Services, University of Haifa; Peter Bamberger, Davidson Faculty of Industrial Engineering and Management, Technion: Israel Institute of Technology; Marilena Bertolino, Department of Cognitive Science and Education, University of Trento; Marco Mariani, Department of Educational Science, University of Bologna; Franco Fraccaroli, Department of Cognitive Science and Education, University of Trento; Tomoki Sekiguchi, Graduate School of Economics, Osaka University; Betty Onyura (Kenya), Department of Psychology, University of Guelph; Hyuckseung Yang, Department of Management, Yonsei University; Neil Anderson and Arne Evers, University of Amsterdam; Oleksandr Chernyshenko, University of Canterbury; Paul Englert, OPRA Consulting Group; Hennie J. Kriek, Research and Development, SHL and Department of Industrial and Organizational Psychology, University of South Africa; Tina Joubert, SHL; Jesús F. Salgado, Departmento de Psicologia Social, University of Santiago de Compostela; Cornelius J. König and Larissa A. Thommen, Psychologisches Institut, Universität Zürich; Aichia Chuang, National Taiwan University; Handan Kepir Sinangil, Business Administration Department, Organizational Behavior Division, Marmara University; Mahmut Bayazit, Department of Management, Sabanci University; Mark Cook, University of Wales; Winny Shen and Paul R. Sackett, Department of Psychology, University of Minnesota.

Oleksandr Chernyshenko is now at the Nanyang Business School, Nanyang Technological University, Singapore.

This research was conducted while Antonio Mladinic was on leave from the Pontificia Universidad Católica de Chile and holding a visiting appointment at the University of Texas at El Paso, and Herman Aguinis was on sabbatical leave from the University of Colorado Denver and holding a visiting appointment at the University of Salamanca (Spain). Authors from each country contributed equally to this paper. Author names are ordered within country, with countries listed in alphabetical order. 
responding to each question and describing the legal environment in their country. They were also invited to suggest additional project participants in other countries. Some invitees declined; some initially agreed but subsequently did not participate. The goal was to obtain a range of perspectives by sampling about 20 countries, and thus, this is by no means a complete catalog of the legal environment around the world. Researchers and practitioners who are experts on the topic of selection from 22 countries participated: Australia, Belgium, Canada, Chile, France, Germany, Greece, India, Israel, Italy, Japan, Kenya, Korea, Netherlands, New Zealand, South Africa, Spain, Switzerland, Taiwan, Turkey, United Kingdom, and United States. As the list indicates, the countries covered do broadly sample the world.

The initial plan was to keep each write-up intact, resulting in essentially 22 separate commentaries that would be presented in sequence. As the commentaries were received, it became clear that write-ups were often quite lengthy, and bundling them would result in a several-hundred-page document. It also seemed more useful to the reader to organize input by issue (e.g., what groups are protected; is preferential treatment of minority group members permitted), rather than by country. Paul Sackett and Winny Shen attempted to extract and categorize information from the individual commentaries into summary formats. In some cases, this involved extracting narrative text from the commentaries; in other cases, pieces of information were extracted and presented in tabular format (e.g., one master table of protected groups in each country).

Contributing authors from each country responded to a number of questions, eight of which are addressed in this article:

1. Are there racial/ethnic/religious subgroups such that some are viewed as "advantaged" and others as "disadvantaged"?

2. Is there research documenting mean differences between groups identified above on individual difference measures relevant to job performance?
3. Are there laws prohibiting discrimination against specific groups and/or mandating fair treatment of such groups? Which groups are protected? Which employers are covered? Which employment practices are covered (e.g., selection, promotion, dismissal)?

4. What is required as prima facie evidence of discrimination? What is required to refute a claim of discrimination?

5. What are the consequences of violation of the laws?

6. Are particular selection methods limited or banned as a result of legislation or court rulings?

7. What is the legal status of preferential treatment of members of protected groups (e.g., quotas or softer forms of preference)?

8. How have laws and the legal environment affected the practice of $\mathrm{I}-\mathrm{O}$ psychology in this country?

Each of these questions is addressed in turn.

\section{Question 1}

Are there racial/ethnic/religious subgroups such that some are viewed as "advantaged" and others as "disadvantaged"?

Table 1 identifies the major groups viewed as disadvantaged in each country. This "snapshot" is elaborated on in the text below, which gives a brief overview of each country's situation, with the intent of giving the reader some context for the situation in each country.

Australia. British colonization of Australia began in 1788, with successive waves of state-sponsored migration, first of convicts and later of free settlers, occurring throughout the 19th century and well into the 20th century. White settlement gradually displaced the indigenous population of Aboriginal and Torres Strait Islanders who had occupied the land for at least the previous 40,000 years. A racially motivated immigration policy in favor of Europeans, the "White Australia policy," existed from Federation in 1901 until 1973, although easing of the 
Table 1. Disadvantaged Groups Within Each Country

\begin{tabular}{|c|c|c|}
\hline Country & Group & $\%$ of population \\
\hline Australia & Indigenous Australians & 2.5 \\
\hline \multirow[t]{3}{*}{ Belgium } & Non-Western immigrants & \\
\hline & Moroccan & 0.8 \\
\hline & Turkish & 0.4 \\
\hline \multirow[t]{4}{*}{ Canada } & Immigrants & 18.4 \\
\hline & Visible minorities & 13.4 \\
\hline & First Nations peoples & 2.1 \\
\hline & Francophones & 15.7 \\
\hline \multirow[t]{5}{*}{ Chile } & Recent immigrants & 1.2 \\
\hline & Argentina & \\
\hline & Peru & \\
\hline & Bolivia & \\
\hline & Ecuador & \\
\hline \multirow[t]{5}{*}{ France } & Immigrant groups & 7.4 \\
\hline & European & 3.33 \\
\hline & North African & 2.22 \\
\hline & Other African & 0.67 \\
\hline & Asian & 0.96 \\
\hline \multirow[t]{4}{*}{ Germany } & Migrant workers/immigrants & \\
\hline & Turkish & 3.7 \\
\hline & Southern European countries & \\
\hline & Reimmigrants (Volga-Germans) & 2.8 \\
\hline \multirow[t]{5}{*}{ Greece } & Immigrants & 7.0 \\
\hline & Albanian & \\
\hline & Bulgarian & \\
\hline & Georgian & \\
\hline & Romanians & \\
\hline \multirow[t]{5}{*}{ India } & Within Hindu castes & \\
\hline & Scheduled castes & 15.06 \\
\hline & Scheduled tribes & 7.51 \\
\hline & Other backward classes & 43.70 \\
\hline & Muslims & 13.0 \\
\hline \multirow[t]{7}{*}{ Israel } & Palestinian Arabs & 22.0 \\
\hline & Druze & 2.0 \\
\hline & Sephardic Jews & 31.0 \\
\hline & Iraq & \\
\hline & Iran & \\
\hline & Morocco & \\
\hline & Ethiopia & \\
\hline \multirow[t]{5}{*}{ Italy } & Albanian & 1.0 \\
\hline & Rumanian & 0.9 \\
\hline & Moroccan & 0.9 \\
\hline & Ukrainian & 0.4 \\
\hline & Chinese & \\
\hline \multirow[t]{4}{*}{ Japan } & North and South Korean & 0.5 \\
\hline & Chinese & 0.4 \\
\hline & Brazilians & 0.2 \\
\hline & Philippines & 0.1 \\
\hline
\end{tabular}

(continued) 
Table 1. (continued)

\begin{tabular}{|c|c|c|}
\hline Country & Group & $\%$ of population \\
\hline \multirow[t]{6}{*}{ Kenya } & Foreigners & 1.5 \\
\hline & Asians & \\
\hline & Europeans & \\
\hline & Muslims & 7.0 \\
\hline & Less populous Kenyan tribes & 51.5 \\
\hline & $\begin{array}{l}\text { (Swahili, Kalenjin, Kamba, Kisii, } \\
\text { Ameru, Embu, Maasai, Somali, } \\
\text { Turkana. Taita and Samburu) }\end{array}$ & \\
\hline Korea & Foreigners & 0.8 \\
\hline \multirow{5}{*}{ Netherlands } & Non-Western immigrants & 10.5 \\
\hline & Turkish & 2.2 \\
\hline & Moroccan & $\begin{array}{l}2.2 \\
2.0\end{array}$ \\
\hline & Surinamese & $\begin{array}{l}2.0 \\
2.0\end{array}$ \\
\hline & Antillean/Aruban & $\begin{array}{l}2.0 \\
0.8\end{array}$ \\
\hline \multirow{2}{*}{ New Zealand } & Pacific peoples & 6.4 \\
\hline & Maori & 13.5 \\
\hline \multirow[t]{4}{*}{ South Africa } & Black (disadvantaged majority) & \\
\hline & African & 79.5 \\
\hline & Colored & 8.9 \\
\hline & Indian & 2.5 \\
\hline \multirow[t]{9}{*}{ Spain } & Immigrant groups & 9.25 \\
\hline & Moroccan & 1.16 \\
\hline & Ecuadorian & 1.01 \\
\hline & Rumanian & 0.89 \\
\hline & Colombian & 0.59 \\
\hline & Argentinean & 0.43 \\
\hline & Bolivian & 0.31 \\
\hline & Chinese & 0.22 \\
\hline & Peruvian & 0.21 \\
\hline \multirow[t]{5}{*}{ Switzerland } & Immigrant groups & 21.9 \\
\hline & Ex-Yugoslavia & 4.7 \\
\hline & Italians & 4.1 \\
\hline & Portuguese & 2.5 \\
\hline & Germans & 2.4 \\
\hline Taiwan & Taiwanese aborigines & 2.0 \\
\hline \multirow[t]{9}{*}{ Turkey } & Religious minorities & \\
\hline & Alevi & 20.0 \\
\hline & Christian and Jewish & 0.3 \\
\hline & Kurdish & 11.0 \\
\hline & Arabic & 1.5 \\
\hline & Other & 1.8 \\
\hline & Armenian & \\
\hline & Greek & \\
\hline & Jewish & \\
\hline \multirow[t]{5}{*}{ United Kingdom } & Indian & 1.78 \\
\hline & Pakistani & 1.26 \\
\hline & Black Caribbean & 0.95 \\
\hline & Black African & 0.82 \\
\hline & Bangladeshi & 0.48 \\
\hline
\end{tabular}


Table 1. (continued)

\begin{tabular}{clc}
\hline \hline Country & \multicolumn{1}{c}{ Group } & \% of population \\
\hline & Chinese & 0.41 \\
United States & Other & 2.1 \\
& Black/African American & 12.3 \\
& Hispanic/Hispanic American & 12.5 \\
& Native American & 0.9 \\
& and Alaskan Native & \\
\hline
\end{tabular}

policy can be traced from the end of World War II. The following groups make up more than $1 \%$ of the population (Australian Bureau of Statistics [ABS], 2007): Australian (nonindigenous), 73.8\%; United Kingdom, 5.6\%; Australian (indigenous), 2.5\%; New Zealand, $2.2 \%$; Italy, $1.1 \%$. Non-English-speaking migrants constitute about $6 \%$ of the workforce (ABS, 2004).

White, English speakers are identified as the majority group, with the most disadvantaged being indigenous people. Indigenous Australians are significantly disadvantaged on virtually all key indicators, including unemployment and income as well as educational attainment, imprisonment, and life expectancy (Steering Committee for the Review of Government Service Provision, 2005). The National Aboriginal and Torres Strait Islander Social Survey (Linacre, 2002) indicated that although indigenous participation rates and incomes have increased since 1994, the gap between indigenous and nonindigenous incomes has not reduced at all.

Belgium. In 2004, the Belgian population included $8.34 \%$ with a foreign nationality (General Board Employment and Labor Market, 2006). Most of the immigrants (66\% of the foreign population in 2004) originate from countries belonging to the European Union (EU), with most immigrants coming from Italy and from Belgium's neighboring countries, France and the Netherlands $(21 \%, 13 \%$, and $12 \%$, respectively, of the total foreign population in 2004). After the Second World War, Italian immigrants were encouraged to enter the Belgian labor market, mostly to fill manual labor jobs (e.g., mine industries), with non-Western immi- grants from Morocco and Turkey $(9 \%$ and $5 \%$, respectively, of the total foreign population in 2004 or $0.8 \%$ and $0.4 \%$ of the total population) encouraged to enter during the 1960s and 1970s to fill this same role. Usually, the Belgians are referred to as the (advantaged) majority group and the nonWestern immigrants as the (disadvantaged) minority group (Okkerse \& Termote, 2004). The actual proportion of these minority groups in the Belgian population is somewhat larger, as a considerable number of non-Western immigrants (and their children) have been granted the Belgian nationality.

The labor force is very similar to the population in terms of foreign nationality. In $2004,23.2 \%$ of the labor-active foreigners were unemployed versus $8.5 \%$ of the laboractive Belgians. The unemployment rate in both the Moroccan and the Turkish minority groups is high: 45\% in 2004 (General Board Employment and Labor Market, 2006; Okkerse \& Termote, 2004).

Canada. First Nations peoples (Indians and Inuit) are the aboriginal population of Canada. European peoples, notably of British and French origin, began colonizing the northern half of North America, which is now Canada, in the 1500s and 1600s. Since Confederation, the establishment of Canada as a country in 1867, federal government policies have resulted in greater immigration than most other countries. After arrival, immigrants become part of a multicultural society that, to varying degrees, protects and supports the language and culture of the home country. Canada has a low birth rate, ranking 186 out of 224 countries in the world in 2006 in terms of births per 
1,000 persons per year. The result is an aging population, and most provinces in Canada have removed the retirement age.

To maintain economic growth and increase labor market participation, Canada actively promotes immigration from other countries, and presently, Canada has one of the highest per capita immigration rates in the world. At present, many immigrants come from Asia, including South Asia, and Africa. Preference for entry is given to skilled workers, business owners, and refugees. At present, about $18 \%$ of the population of more than 30 million is foreign born. There is considerable societal concern over historical underrepresentation of visible minorities (more than 4 million individuals), aboriginals (more than 900,000 individuals), and women in higher level and better-paid positions across the Canadian economy. Persons from the aboriginal and visible minority groups have higher unemployment and poverty rates than the majority population. Employment equity legislation is in place for federal government employees. Federal employers such as the Canadian Forces also monitor their workplace practices to promote equal representation of Francophones, primarily from the province of Quebec, with Anglophones from the rest of Canada.

Chile. According to the 2002 census, about $4.6 \%$ of the total population identifies with a nonnative ethnic group. Immigrants from Europe (particularly Spain, Germany, Croatia, Eastern Europe) and the Middle East were encouraged to migrate to Chile in the late 1800 s and early 1900 s. They usually settled in rural areas or in urban areas including small towns. The descendants of these minority ethnic groups have become more prominent and influential over time and can currently be labeled as "advantaged minority" groups.

More recent immigrants make up a small percentage of the population $(1.2 \%$ according to the 2002 census); however, this is the highest percentage of immigrants since 1952. There are some estimations that the number of immigrants is increasing but not by a significant number. These new immigrants are mainly from other South American countries (Argentina, Peru, Bolivia, and Ecuador). Most of them hold blue-collar, low-skill jobs; a small proportion of these immigrants are professionals. However, the distribution of the more recent immigrants by industry type does not differ substantially from the general Chilean population. The only exceptions are Peruvian women who, in general, work as housekeepers.

France. It is widely recognized in France today that racial discrimination is widespread, especially against people of North African origin. This population had a major immigration period in France starting in the 1960s following the independence of these countries from France. Other ethnic minorities are also represented by immigration from other African countries, especially those that were former French colonies. Throughout the past decades, the geographical origins of immigrants have become more diverse and distant. In 1962, immigrants from Spain and Italy represented half of the immigrants residing in France; by 1999, they only represented one in six immigrants. Inversely, the proportion of North African immigrants doubled during that period, and they now represent $30 \%$ of immigrants. In 1999, the immigrant population (7.4\% of the French population) had the following composition: 45\% European, 30\% North African, 9\% other African, and 13\% Asian (Bourlès \& Courson, 2000).

Concerning the minority composition of the workforce, in France, it is rather difficult to know it exactly. In fact, one of the guiding principles of equality in France is the belief that equality is best guaranteed by not collecting such information. Thus, it is illegal for organizations to keep records on the ethnic group membership of their employees. Recent recommendations (Fauroux, 2005) for fighting discrimination in France question this practice and suggest that it may be useful to keep such records in order to know better the potential extent of discrimination against various groups.

That being said, some data are available and they indicate that immigrants represent $8 \%$ of employed people. Generally, 
immigrants have blue-collar labor jobs: $46 \%$ of them are employed in this category compared to $25 \%$ of nonimmigrants. Unemployment is also higher among immigrants: $18 \%$ for immigrants compared to $9 \%$ for nonimmigrants (Attal-Toubert \& Lavergne, 2006). Unemployment rates vary depending on the origin of the immigrants: For those from Spain, Italy, or Portugal, unemployment is low, lower even than that for nonimmigrants. On the other hand, North African, sub-Saharan African, and Turkish origin immigrants have high rates of unemployment. For those aged from 25 to 59 years, about one in five is unemployed (Tavan, 2005).

Germany. In Germany, there are mainly two groups today regarded as disadvantaged minorities: migrant workers and reimmigrants. Starting in the mid-1950s, migrant workers came to Germany mainly from southern European countries and Turkey to strengthen the workforce in a rapidly growing economy. Today, nearly 7.3 million "foreigners" are living in Germany (with a total population of 82.4 million), not including several million persons of foreign origin who were already nationalized. A high proportion of these persons are working in lowlevel jobs, have low levels of education, and low language skills. They and their offspring are now highly overrepresented in unemployment rates (i.e., about $20 \%$ vs. $8 \%$ ). Roughly, the same is true for reimmigrants from Russia, the so-called Volga-Germans, who are treated as Germans but nonetheless lack German language skills. Minority problems in Germany are not discussed in terms of race. Religion is seen as a cultural problem (especially that of Muslim integration) but not as a problem in an occupational context.

Greece. In Greece, the migration trends are linked to the political and financial changes and upheavals in the wider area of the Balkan Peninsula. Through the first half of the 20th century, the migration flow was outward, with Greek citizens migrating to other countries, mainly the United States, Germany, and Australia. In the early 1990s, an immense flow of immigrants from the neighboring countries took place (Papadopoulou, 2005).

Of the total population, $93 \%$ was made up of people of Greek origin, 7\% foreigners (both EU and non-EU). Albanians constitute some $56 \%$ of total population of immigrants, followed by Bulgarians (5\%), Georgians (3\%), and Romanians (3\%), and their representation in the labor force approximates their representation in the population $(58 \%$, $6.7 \%$, and $4.2 \%$, respectively). The interesting issue here is the fact that Greece is the only EU country having one dominant immigrant group in excess of $50 \%$ of its immigrant population (Baldwin-Edwards, 2004). Regarding the immigrants' main occupation, the principal employment has been in building construction (around 70\%), followed by agriculture $(11 \%)$, industry $(8 \%)$, and tourism (5\%) (Baldwin-Edwards, 2004). The mean percentage of immigrant unemployment is lower than that of the mean of the country (9.2\% vs. $11.0 \%)$. Illegal immigrants are not included in these figures.

An additional issue is the phenomenon of repatriates. This illustrates that some immigrant groups may be considered as advantaged compared to others. Certain laws (1990: 2130, 2000: 2790, and 2000: 4864/ 8/8c) reinforce the concept of "repatriated Greeks" by establishing rapid procedures for granting Greek citizenship and favorable benefits to claimants from regions of the former Ottoman Empire and Commonwealth of Independent States (CIS, formerly the USSR). Additionally, Greek Cypriots are considered an advantaged minority group primarily because of their privileged status.

India. As per the census of 2001, the population of India is 1,028 million, and the total workforce of India is estimated to be about 397 million. Though it is $16.7 \%$ of the world's total population, India is only $2.4 \%$ of the total geographical area of the earth (National Informatics Centre, India, 2005). There are six main religious groups in India. Although Hindus constitute around $83 \%$ of the population, Muslims constitute about 13\% Christians about 2.5\%; and the rest are Jains, Sikhs, Buddhists, and others. The 
majority of Hindus are further divided into castes, which are arranged in a socioreligious hierarchy. A caste is defined as "an endogamous and hereditary subdivision of an ethnic unit occupying a position of superior or inferior rank or social esteem in comparison with other such sub divisions" (Kroeber, 1937). The Brahmins are considered to occupy the top place in the hierarchy, and the scheduled castes and scheduled tribes castes are given special protections and are eligible for affirmative action measures by the Indian Constitution because of their historical exclusion from Hindu society where they were considered outcasts and allowed virtually no socioeconomic, educational, or upward mobility opportunities, the bottom of the hierarchy. There are 2,399 identified castes among the Hindus, of which about $66 \%$ are considered to be socially and economically backward (National Commission for Backward Classes, 2005). The Indian constitution defines backward classes as those who have ideas of ceremonial purity, restrictions on intercaste marriage, taboos on food and drink, and social segregation.

Although $56.6 \%$ of the total employees in the central government services are from forward castes, $19.0 \%$ are from backward classes and $24.4 \%$ from scheduled caste/tribes (Government of India, 1980). As per the policy of the Government of India, reservation for scheduled castes/scheduled tribes in direct recruitment was provided in the following percentages: scheduled castes, $15 \%$; scheduled tribes, $7.5 \%$; and other backward classes, $27 \%$. Muslims are also considered to be a disadvantaged minority in India and are underrepresented in various employment sectors.

Israel. Israel is a multicultural society populated by three primary ethnic groups, namely, Hebrew-speaking Jews (76\% of the population, the "majority group"), Arabic-speaking Palestinians $(22 \%$ of the population), and Druze ( $2 \%$ of the population) (Central Bureau of Statistics [CBS], Israel, 2006). The Jews are themselves a multicultural group as they are all immigrants or decedents of immigrants from more than
100 countries of the Jewish Diaspora. Nearly $20 \%$ of the Jewish population are recent immigrants from the former Soviet Union, and $31 \%$ are immigrants or decedents of immigrants from Asian and African countries (e.g., Iraq, Iran, Morocco, Ethiopia, i.e., "Sephardic" Jews) (Leshem, 2004). Similarly, although most Palestinians are Muslim, approximately $10 \%$ are Christian (i.e., Orthodox or Catholic).

Although the representation of Jews and Arabs in the working-age population parallels their proportionate representation in the population overall, because of low female Arab labor force participation (LFP) rates the relative proportion of Jews in the workforce is greater than that of Jews in the working-age population $(86 \%$ for proportion of Jews in the workforce vs. $81 \%$ for proportion of Jews in working-age population). Specifically, LFP rates are $60 \%$ for Jewish males and $51 \%$ for Jewish females, the latter having increased from just under $30 \%$ in 1970 (CBS, Israel, 2006). In contrast, the LFP rates for Palestinians are $65 \%$ for males and $22 \%$ for females (Pines, 2003). Three groups are typically considered disadvantaged in the labor market, namely, Palestinian Arabs, Sephardic Jews, and females. With the majority of Palestinian Arabs continuing to be employed primarily in blue-collar jobs, such as construction and manufacturing (Blumen, 2007), the pay of male salaried employees continues to be over $20 \%$ higher than that of females on average (Israel Ministry of Industry and Trade, 2007) and higher unemployment rates for females and Arabs relative to male Jews $(9.5 \%$ and $12.8 \%$ vs. $8.3 \%$, respectively); concerns regarding employment and income disparities remain major issues in the Israeli political landscape.

Italy. The phenomenon of immigration into Italy began relatively recently, after the oil crisis of 1973-1984 when England, Germany, and especially the neighboring country of France closed their frontiers to immigration. This resulted in migratory flows being partly "diverted" toward southern Europe, with Italy functioning as a transit country for other destinations for a number 
of years. Immigration into Italy continued slowly during the 1960s-1970s with people coming primarily from poor African countries, looking for better working conditions. During the 1990s, a big wave of immigrants (most of them clandestine) coming from ex-Yugoslavia countries and Albania took place. Most of these people left their homelands because of the military conflict, looking for a better life, and overall stable working conditions. So, the causes of immigration into Italy are poverty, war, underdevelopment, and the availability of natural resources.

Immigrants from different countries make up $7 \%$ of the population: $13.7 \%$ of immigrants are from Albania, 13\% from Rumania, $12.2 \%$ from Morocco, 5.4\% from Ukraine, and $5 \%$ from China (Bonifazi, 2007). Globally, in Italy, the distribution of the immigrant population that was working in 2005 was around $87.2 \%$ compared with $73.7 \%$ of working Italians. The same was true for women but at a lower level: $58.1 \%$ of women immigrants and $50 \%$ of Italian native women were employed. In Italy, immigrants generally do hard, badly paid jobs, which are rejected by the local population, such as working in marble quarries, building trades, tanneries, dock workers, and agricultural jobs such as grape harvesting and picking vegetables and fruits.

Japan. Of the total population, 98.4\% are pure Japanese who speak Japanese as their first language (technically the figure includes all naturalized people regardless of race), and the rest $(1.6 \%)$ are foreign residents (Immigration Bureau, Japan, 2006). North and South Koreans account for $28.7 \%$ of Japan's resident aliens, followed by Chinese $(26.9 \%)$, Brazilians $(15.0 \%)$, and Filipinos $(9.3 \%)$. The number of foreign workers accounts for $1.3 \%$ of Japan's total workforce. North and South Korean account for 28.9\% of the total foreign workers, followed by Chinese $(23.6 \%)$, Brazilians (18.1\%), and Filipinos (8.2\%) (Statistics Bureau, Japan, 2006). Those foreign residents are considered to be the disadvantaged minority in Japan.

As an island nation, the Japanese population has been ethnically homogeneous for a long period of time. During the Japanese occupation of Korea from 1910 to 1945, many Koreans migrated or were forced to migrate to Japan for work, and those who remained to stay without being naturalized after the end of World War II became the largest foreign population group in Japan. In recent years, there has been an influx of people from other Asian countries such as China and the Philippines, and the number of Central and South Americans of Japanese descent who have immigrated to Japan with their families to work is also on the rise (Japan Institute of Labor Policy and Training, 2007).

Kenya. Kenya has enjoyed relative political stability since it obtained independence from British rule in 1963. It is home to a diverse group of people from different language groups and ethnic backgrounds. Native Kenyans belong to more than 40 distinct language groups, commonly referred to as tribes. The three largest tribal groups (Kikuyu, Luhyia, and Luo) make up approximately $46 \%$ of Kenya's population. Other native Kenyan tribes make up approximately $51.5 \%$ of the population, whereas Kenyans of European and Asian origin make up about $1.5 \%$ of Kenya's population (Kenya National Bureau of Statistics, 2003). Kenya's population is distributed (albeit unevenly) among eight provinces. The Rift Valley is the most populous province, with a population of more than 7 million, whereas North Eastern province is the least populated, with a population of just below 1 million. With the exception of Nairobi province, which hosts the nation's capital, individual tribal groups tend to live within the same geographic area.

Kenya has serious problems with regard to resource distribution among its provinces and communities. Most of the extremely poor people are to be found in northern and western Kenya, whereas the least poor are in Central, Rift Valley, and Nairobi provinces. North Eastern province and parts of Nyanza, Western, Coast, and Eastern provinces have much lower indicators of mortality, health facilities, safe water, sanitation, communication, and transportation in comparison to the rest of the country. This is in 
large part a result of colonial and postcolonial policy biases that saw areas with abundant natural resources draw greater economic investment than others. Some provinces are also disadvantaged by harsh environmental conditions. Feelings of discrimination and social disadvantage are also common among ethnic and religious groups that are not well represented in the political sphere (e.g., Muslims and Kenyans of Asian origin). For Kenyan Muslims, their feelings of discrimination are compounded by the fact that the majority of the residents in the economically disadvantaged North Eastern province are Muslim.

Korea. Korean society is a representative one that is dominated by a single racial/ethnic group (called Han-Gook-In). Although there are some other ethnic groups, the proportion is so small that they are not classified in the Population Census conducted every 5 years. A phrase of "a nation composed of a single ethnic group" (called Dan-Il MinJok-Goog-Ga) has played a significant role in strengthening the solidarity and unity among Korean people.

However, since 1990, inflows of foreign workers have been gradually increasing mainly because of the lack of laborers in second-tier labor markets. In 2005, foreign workers including illegal residents were estimated to be about $0.8 \%$ of the workforce. In addition, people who get married to foreign partners are gradually increasing. In 2005, $13.6 \%$ of newly formed families are multicultural and $0.4 \%$ of total families are multicultural (Korea National Statistics Office, 2006).

Netherlands. Of the total population, $80.7 \%$ was made up of people from Dutch origin, $8.7 \%$ of immigrants from other Western countries (Europe, North America, Oceania, Japan), and $10.5 \%$ of immigrants from non-Western countries (Africa, Turkey, Asia, Latin America). Usually, the Dutch are referred to as the advantaged majority group and the non-Western immigrants as the disadvantaged minority group. The biggest minority subgroups are Turkish (2.2\%),
Moroccan (2.0\%), Surinamese $(2.0 \%)$, and Antillean/Aruban (0.8\%).

Immigrants, particularly from Turkey and Morocco, were encouraged to enter the Dutch labor market during the 1960s and 1970s, largely to fill blue-collar and manual job vacancies at the same time. The immigration from the former Dutch colonies, Surinam and the Antilles/Aruba, started at about the same. At first, this group consisted of highly educated people who came to the Netherlands for advanced education and work in administration and health care. Later on, this changed with an increasing proportion of predominantly low-educated people entering the Netherlands for bluecollar work (Tesser, Merens, \& van Praag, 1999). Since then, second and third generations of these minority groups have become more prominent, especially in the large cities such as Amsterdam, Rotterdam, and Den Haag. For instance, in the city of Amsterdam, $66 \%$ of the pupils in primary schools are of non-Western origin (Dienst Onderzoek en Statistiek Gemeente Amsterdam, 2007).

The distribution of working-age population (15-64 years) is roughly the same as the total population, although the portion of especially the Turkish and Moroccan subgroups is somewhat lower because of lower participation of women and a higher proportion of children (CBS Statline, 2007).

New Zealand. Of the total population, $62.4 \%$ are of European origin (includes those born in New Zealand or abroad), 13.5\% Mäori, 6.4\% Pacific Peoples, 8.5\% Asian, and $0.8 \%$ people from the Middle East, Latin America, or Africa. Usually, the Europeans are referred to as the majority group and the rest as minority groups. The LFP rate in New Zealand has been climbing steadily. In 2006, it was at $68.1 \%(75.2 \%$ males and $61.3 \%$ females). The overall unemployment rate was $3.7 \%$ in 2006 . European subgroup had the lowest unemployment rate of $2.6 \%$, followed by Pacific Peoples and Asians (6.4\% each), and Mäori $(8.6 \%)$. Although there are still some appreciable ethnic differences in unemployment 
rates, this gap has declined dramatically in the past 10 years. Prior to 1840, New Zealand's economy and society were effectively controlled by its indigenous people, Mäori, who were of Polynesian decent and settled the country between 950 and 1130 AD. Yet, the influx of mainly British immigrants has created a necessity for more formal government structures than traditional tribal laws to oversee the British populated areas of New Zealand. Great Britain prepared a treaty with Mäori granting them the same rights as those of all British subjects in exchange for them accepting the sovereignty of the Queen. Mäori would also retain possession of their lands and fishing areas, whereas the new Colonial government would have a preemptive right to purchase land. This treaty, known as Treaty of Waitangi, was signed on February 6,1840 , by a large proportion of Mäori chiefs. Initially, very limited legal weight has been given to the Treaty, so Mäori, being British subjects, received no preferential treatment under the law. However, in recent years, there has been greater recognition of the legal status of the Treaty, such that the Parliament, for example, is now required to ensure that the proposed bills are consistent with the principles of the Treaty (e.g., consult Maori groups on decisions that may affect them, protect Maori interests, and redress past injustices). Mäori and Pacific Peoples (recent immigrants from the Pacific Islands of Tonga, Samoa, etc.) are underrepresented on income and higher education statistics while overrepresented on crime, poor health, and employment benefits statistics. On the other hand, the Asian subgroup generally performs as well or better than the European group and, thus, is not commonly viewed as disadvantaged. The data for the Middle East/ Latin America/Africa subgroup are currently too small to draw meaningful conclusions.

South Africa. The Employment Equity Act (EEA) in South Africa classifies the South African population into two ethnic groups-Black and White. The Black group is then further subdivided into African, colored, and Indian. Africans are in the majority $(79.5 \%)$, then Whites $(9.2 \%)$, colored $(8.9 \%)$, and Indian
(2.5\%). With regard to migration data, the 2006 mid-year population estimates for South Africa estimates that the large out-migration of Whites will decline over time and the immigration of Africans will continue.

South Africa has a long history of segregation and apartheid between the different racial groups. Blacks were forced to go to "Bantu" schools where the educational level was very poor and the White government reserved skilled work for the Whites. The policy of the Black schools was aimed to direct the Black youth to the unskilled labor market (Rebirth, 2000). The Whites were and still are referred to as the advantaged minority and the Blacks (African, colored, and Indian) as the disadvantaged majority. The census of 2001 shows that the largest group of African (36.3\%) and colored $(34.3 \%)$ workers was employed in elementary occupations, whereas the largest groups of White $(52.6 \%)$ and Indian (38.6\%) workers were employed in managerial positions.

The first democratic election in South Africa was held in 1994 where the African National Congress and Black people emerged with a majority victory. They embarked on a program to promote reconstruction and development for the previously disadvantaged and attempted to integrate South Africa into a rapidly changing global environment (South Africa Celebrating Diversity, 2007). Affirmative action, a social policy that is aimed at reducing the effects of racial discrimination, was introduced into the labor market to redress the mistakes of the past. The EEA (55 of 1998) enforces affirmative action and states that every employer must implement affirmation action measures to achieve equity in the workplace. The quota interpretation of affirmative action is in the order of the day and means that organizations will employ certain predetermined percentages of employees from the previously disadvantaged groups, within a specific time frame (Muchinsky, Kriek, \& Schreuder, 2003).

Spain. The total Spanish population in 2006 was $90.8 \%$ Spaniards and $9.3 \%$ immigrants. These immigrants come from Latin 
America (38.9\%), EU (21.9\%), Europe non-EU (16.8\%), Africa (19.1\%), and Asia (5.1\%). The biggest immigrant subgroups are Moroccan $(12.51 \%)$, Ecuadorian (10.88\%), Rumanian $(9.6 \%)$, Colombian (6.4\%), Argentinean $(4.6 \%)$, Bolivian $(3.34 \%)$, Chinese $(2.4 \%)$, and Peruvian $(2.3 \%)$. It is important to notice here that two important immigrant subgroups (British and German) are mostly retired older people who are living in the Mediterranean coast and the Canary Island. The number of immigrants increased by about 50\% between 2003 and 2006, not only because of new immigrants but also because of processes opened by the Spanish government by which illegal immigrants can obtain permission for residence. The distribution in the working-age population (1664 years) is roughly the same as the total population. The unemployment rate for the majority group was $8.55 \%$ compared with $12.80 \%$ for the immigrant group. The majority of the unemployed immigrants are nonEU citizens ( $12.7 \%$ vs. $0.1 \%)$.

Switzerland. Foreigners represent $21.9 \%$ of the overall population and $25.3 \%$ of the working-age population in Switzerland (Federal Statistical Office, 2006a). Nearly a quarter of all foreigners (23.3\%) were born in Switzerland. The four largest immigrant groups are people from ex-Yugoslavia, Italians, Portuguese, and Germans. The first group has come to Switzerland comparatively recently (mainly in the 1990s) and probably faces the most discrimination (e.g., Krings \& Olivares, 2007). Of further note are the extensive naturalization requirements and procedures. Consequently, compared to other European countries, Switzerland shows one of the lowest naturalization rates (2.5 per 100 foreigners living in Switzerland; Federal Statistical Office, Switzerland, 2006a).

On average, the non-Swiss show a considerably higher unemployment rate $(6.4 \%)$ than the Swiss $(2.8 \%)$ and have jobs that require less qualification compared to jobs held by the Swiss (Federal Statistical Office, Switzerland, 2006a). However, these statements must be qualified by taking into account the countries of origin of these immigrants. Whereas $47 \%$ of immigrants coming from northern or western Europe work in academic jobs or at a managerial level, only $5 \%$ of immigrants from ex-Yugoslavia (and $25 \%$ of the Swiss) hold such positions. Similarly, unemployment is much more common among immigrants from exYugoslavia than among immigrants from northern or western Europe (Federal Statistical Office, Switzerland, 2006a).

According to its Federal constitution, Switzerland has four national languages: German, French, Italian, and RhaetoRomanic. They are not equally distributed across the country but make up four language areas, each of which has its own predominant language. The majority of the Swiss population is German speaking $(63.7 \%)$, followed by the French- and Italian-speaking Swiss $(20.4 \%$ and $6.4 \%$, respectively; Federal Statistical Office, Switzerland, 2006b). The minority group of Rhaeto-Romanic speakers constitutes no more than $0.5 \%$ of the Swiss population, far less even than is accounted for by other nonnational languages (9.0\%). With regard to the languages used in work settings, each of the four languages is used as a main work language in their respective language areas. There is, however, a high rate of bilingualism in the Rhaeto-Romanic area (German and Rhaeto-Romanic), whereas the other language areas show a much more limited use of other national languages (Lüdi \& Werlen, 2005). Differences can further be found regarding unemployment rates, with figures being comparatively high for French- and Italian-speaking Swiss (Federal Statistical Office, Switzerland, 2006b).

Taiwan. The population of Taiwan is made up of racial subgroups of Waishengren, Hoklo, Hokka, and the Taiwanese aborigines. Among these subgroups, the aborigines, who are the indigenous peoples in Taiwan, are considered the disadvantaged minority. However, people among the rest are treated equally, and thus, no major advantaged majority exists among them. As 
such, hereafter, the aborigines are referred to as the minority and the rest the majority.

The Taiwanese aborigines are believed to have lived on the islands for approximately 8,000 years before Han Chinese immigration occurred in the 1600s (Blust, 1999). They are Austronesian peoples who were traditionally distributed over the island's central mountains. Today, the majority of the Taiwanese aborigines reside in the mountains and the cities. The aborigines have been experiencing social and economic difficulties including a low education level and high unemployment rate since the immigration. They have been actively seeking promotion of their economic development. In 1996, a central government organization, the Council of Indigenous Peoples, was established to carry out coordination and planning of indigenous affairs.

In 2005, $2 \%$ of the population was made up of the aborigines (Department of Household Registration Affairs, 2005). The percentage of the aborigines in the working-age population (2\%) and the workforce $(2.1 \%)$ was generally the same (Council of Indigenous Peoples, 2005; Directorate-General of Budget, Accounting and Statistics, 2005b). In terms of the occupations held, in 2002, the majority of the aborigines were agricultural, animal husbandry, forestry, and fishing workers (18.37\%); technicians and associate professionals (18.36\%); service workers and shop and market sales workers (15.98\%); and production, machine operators, and related workers (14.77\%) (Council of Indigenous Peoples, 2002). In 2005, the average monthly wage in general was 35,275 New Taiwan Dollars (TWD; approximately 1,074 USD) and that for the aborigines was 31,000 TWD (approximately 944 USD) (Council of Indigenous Peoples, 2005; Directorate-General of Budget, Accounting and Statistics, 2005a). The general unemployment rate was $4.1 \%$ and that for the aborigines was $4.3 \%$ (Council of Indigenous Peoples, 2005).

Turkey. In Turkey, the exact number of ethnic and religious populations is not known because of government policy and practices emphasizing an overarching secular Turkish identity for all citizens of the republic (information on ethnic identity is not requested in the census). According to independent estimates, $85.7 \%$ of Turkish population is Turkish, the remaining includes Kurdish (11\%), Arabic (1.5\%), and other (Armenian, Greek, Jewish; $1.8 \%$ ). There are also religious subgroups in the country. The majority of the population is Sunnî Muslim (80\%). The rest is Alevi (nonorthodox Shî'î Muslim sect, $20 \%)$ and Christian and Jewish (0.3\%).

There is no generally accepted information regarding unemployment levels of specific ethnic and religious groups. Unemployment levels in the east and southeast regions (higher representation of Kurdish minority) of the country are chronically higher $(30 \%)$ than average unemployment rates (9.9\% in 2006) (ATO Report, 2006), though this is largely considered to be an outcome of lack of industrial infrastructure and poor integration of the agricultural economy of the region with the national economy.

Generally, Turkish and Sunnî majority are viewed as the advantaged majority, whereas all the others are considered "disadvantaged minorities" especially when it comes to governmental practices. Although there is much circumstantial evidence (e.g., media reports) of individuals from these groups being subjected to various forms of discrimination (legal, educational, employment), there is no available research on the matter. We believe that a reason for this could be the sensitivity of the issue for both the state and the people.

United Kingdom. In the 2001 census, $7.9 \%$ of the U.K. population described themselves as belonging to an ethnic minority. The principal minorities distinguished by the census are the following: Indian (1.78\%), Pakistani (1.26\%), Black Caribbean $(0.95 \%)$, Black African (0.82\%), Bangladeshi $(0.48 \%)$, and Chinese $(0.41 \%)$. A considerable proportion of minority persons fall into less clearly defined census categories: "other Asian," "Black other," "mixed," or "other ethnicity," totaling 2.1\%. "Asian" in British usage means Indian subcontinent and 
possibly Thailand, Malaysia, etc., but not China and Japan.) Minority persons are not equally distributed through the country but tend to concentrate in certain large cities.

The non-White population of the United Kingdom has for the most part migrated to the United Kingdom since 1945, exercising the right of Commonwealth citizens to settle in the United Kingdom. This right was restricted in the early 1970s, reducing the flow of immigration. It follows that a high proportion of U.K. ethnic minority persons were born in the United Kingdom. Since about 1990, a number of asylum seekers from various countries have settled in the United Kingdom. Since May 2004, citizens of former communist countries that have joined the EU have the right to live and work in the United Kingdom; it is estimated that at least 0.5 million have come. Citizens of the Irish Republic have had the right to live and work in the United Kingdom for many years and have encountered some discrimination in employment in the past.

United States. The U.S. working-age population is $74 \%$ White, $11 \%$ Hispanic/Latino, 11\% Black/African American, 4\% Asian American, and less than $1 \%$ Native American. The percent distribution among those in the workforce is roughly the same $(78 \%, 12 \%$, $8 \%, 4 \%$, and less than $1 \%$, respectively). Thus, the White group is the majority group and Black/African Americans, Hispanic/ Latinos, and Native Americans are the disadvantaged minorities. However, because of, on average, their relative high achievement on educational measures and successful entry into many professional and managerial fields, Asian Americans tend not to be considered a disadvantaged minority group.

The Black/African American group consists in substantial part of descendants of Africans brought to North America as slaves. This continued until the end of the U.S. Civil War of 1861-1865, of which one outcome was the abolition of slavery. Racial segregation continued in parts of the country well into the 20th century with the courts upholding such standards as "separate but equal" until the middle of the 20th century. Issues of income disparities and discrimination in education, housing, employment, and reparations remain major issues in the U.S. political landscape.

The Hispanic-American label describes a variety of cultures (e.g., Mexicans, Puerto Ricans, Cubans, South Americans, Central Americans). Although a portion of Hispanic/Latinos residing in the United States may represent new immigrants from their home countries, many Hispanic/Latino individuals are and have been U.S. residents and citizens. It is difficult to attempt to characterize the history of the Hispanic/Latinos as a group in the United States because of diverse experiences, multiple waves of entry, and large variations in educational levels and socioeconomic status. It is projected that of all the minority groups, the Hispanic/Latino group will have the largest numerical increase $(67$ million or $187 \%$ increase) by 2050 in the United States (U.S. Census Bureau, 2004).

Native Americans/Alaskan natives are considered the indigenous peoples of the Americas and are members or descendents of a number of culturally (and often linguistically) distinct tribes. Issues of poverty, unemployment, low educational attainment, and health and mental health issues continue to plague Native Americans/Alaskan Natives, particularly those who live on reservations.

Summary. As Table 1 and the abovementioned text indicate, the disadvantaged groups differ on a number of dimensions. First, the basis for disadvantaged status varies: (a) native/aboriginal people in a setting where colonizers became the majority group (e.g., United States, Australia, Canada), (b) recent immigrants (e.g., many European countries), (c) racial groups either native to or with long histories in the country (e.g., United States, South Africa), (d) religious groups (e.g., India), and (e) language groups (e.g., Canada, Switzerland). Second, the size of the minority population varies, from a very small percentage of the population in some countries to the South African extreme of a previously disadvantaged Black majority. These findings illustrate that there is considerable 
variability from country to country in what constitutes a disadvantaged group.

\section{Question 2}

Is there research documenting mean differences between groups identified above on individual difference measures relevant to job performance?

Mean differences on ability and personality measures are commonly examined in the United States, with enough data for largescale, meta-analytic summaries. Mean differences on tests of developed abilities of roughly $1 S D$ between Whites and African Americans and roughly $0.67 S D$ between Whites and Hispanics have been consistently reported. The largest scale summary of this literature is a meta-analysis by Roth, Bevier, Bobko, Switzer, and Tyler (2001). Regarding the African American-White mean difference, they report large-scale, metaanalytic mean $d$ values of 0.99 for the SAT, 1.02 for the ACT, 1.34 for the Graduate Record Examination (GRE), 0.99 for employment tests of general ability, and 1.10 for military tests of general ability. Regarding the Hispanic-White mean difference, they report meta-analytic mean $d$ values of 0.77 for the SAT, 0.56 for the ACT, 0.72 for the GRE, 0.58 for employment tests of general ability, and 0.85 for military tests of general ability.

This abundance of data proves to be in marked contrast to the pattern of findings in the countries examined here. In fact, for the majority of countries, the authors reported finding either no research or research with samples so small that they refrained from drawing conclusions (Chile, France, Greece, Italy, Japan, Korea, Spain, Switzerland, Turkey, and the United Kingdom). Although limited, there are some data on group differences in some countries.

There are some data reporting lower cognitive ability scores for Australian aborigines, but there is great concern that differences may reflect language and culture. The official position of the Australian Psychological Society (APS) is that "there are currently no known formal psychological tests that have been developed specifically for use with indigenous people and that provide current-day norms and measurement statistics for indigenous test-takers" (APS, 2003, p. 7). The APS advises that any research using indigenous participants must be conducted with great cultural sensitivity and in close partnership with them.

Data from Taiwan also show a similar trend, with aborigines scoring lower than non-aborigines on a number of cognitive ability tests. Data from the United Arrangement Commission for college entrance examinations in Taiwan in 2006 show differences on Chinese Language and Literature $(d=0.63)$, English $(d=0.48)$, mathematics $(d=0.66)$, history $(d=0.48)$, geography $(d=$ $0.44)$, physics $(d=0.45)$, chemistry $(d=$ $0.58)$, and biology $(d=-0.48)$. However, to the extent that Taiwanese aborigines are typically underrepresented in higher education and have a lower level of educational attainment (Council of Indigenous Peoples, 2002), the cognitive ability differences reported here may not accurately estimate differences in the populations.

Cognitive ability mean score differences have been reported of $d=1.39$ between Turkish/Moroccan immigrants and Dutch test takers, and $d=1.08$ between Surinamese/Antillean and Dutch test takers, in both cases favoring the majority group (te Nijenhuis, de Jong, Evers, \& van der Flier, 2004). Language differences appear to contribute to these findings, as higher scores are found for second-generation immigrants than for firstgeneration immigrants. Studies in Belgium also report mean differences of about $1 S D$ on cognitive tests between Belgians and Turkish and Moroccan immigrants in samples of children (Fontaine, Schittekatte, Groenvynck, \& De Clercq, 2006).

In South Africa, mean score differences on cognitive tests between Black and White groups are normally found to be larger than U.S. studies and is around $d=1.00$ to 1.50 where the Whites obtain the higher mean scores. In a study performed in a South African financial services organization, $d=0.99$ for a verbal ability, $d=1.03$ for a numerical ability, and $d=1.14$ for a diagrammatic ability test were found (see V036 on SHL's Web 
site; SHL, 2006). In South Africa, these differences are largely ascribed to the differences in the educational level of the racial groups. In the 2001 census, it was determined that $22.3 \%$ of Africans, $8.3 \%$ coloreds, $5.3 \%$ Indians, and $1.4 \%$ Whites had no schooling.

Limited data report lower scores for Arabs than for Jews in Israel (Zeidner, 1986), for Canadian aboriginals than for Whites, for New Zealand Maori than for Whites (Chernyshenko, 2005; Guenole, Englert, \& Taylor, 2003), and differences between individuals in various provinces in Kenya (Kinyungu, 2006). Data on personality measures are even more limited than for cognitive ability, with authors reporting personality data from only two countries: a large-scale study of Black-White differences in South Africa (Kriek, 2006), showing small differences, and several studies of Dutch-immigrant differences in the Netherlands, showing much larger differences (te Nijenhuis, van der Flier, \& van Leeuwen, 1997, 2003; van Leest, 1997).

Overall, several findings of interest emerge. First, it is clear that gathering data and reporting mean differences by group are generally far more common in the United States than in virtually all the countries contributing to this report. This is likely the result of the legal scrutiny to which tests are held in the United States. The Uniform Guidelines on Employee Selection Procedures use adverse impact computations as the basis for a prima facie case of discrimination, and thus, adverse impact resulting from test use is routinely examined, with mean differences between groups and the method of test use (e.g., a high or a low cutoff) functioning as key determinants of adverse impact. Second, even though data tend to be more sparse than in the United States, group differences are studied and observed in a variety of settings involving a variety of different types of disadvantaged groups (e.g., immigrant groups in Belgium and the Netherlands; native peoples in Australia, New Zealand, and Canada; tribal and provincial differences in Kenya; the native Black population in South Africa; Arab groups in Israel). Third, as in the United States, there is interest not only in whether there are group differences but also in understanding the basis for these differences. Language, culture, and differences in educational access and attainment are seen as key concerns in understanding differences in test scores across groups.

In the United States, disparate impact is the basis for a prima facie case of discrimination. The implicit assumption is that various groups are expected to obtain similar mean scores absent bias in the measure. Our data suggest that many European countries target certain groups as immigrants to meet specific labor shortages. Thus, immigrants might have higher or lower abilities, depending on whether a country tried to attract high-skilled people (e.g., recent immigrants into Switzerland from northern and western Europe) or tried to attract people with low skills (e.g., Turkish immigrants to Germany). In other words, even if one has a general expectation of no group differences at the population level, a finding of differences between locals and immigrants would be expected, given this targeted immigration.

\section{Question 3}

Are there laws prohibiting discrimination against specific groups and/or mandating fair treatment of such groups? Which groups are protected? Which employers are covered? Which employment practices are covered (e.g., selection, promotion, dismissal)?

Table 2 presents summary information addressing the above-mentioned questions for each country. A number of findings emerge. First, there is some basis for legal protections for members of specified groups in all countries. The bases for these protections vary widely. In many cases, the national constitution provides general, or at times specific, protections. This may be seen as analogous to the 5th and 14th amendments to the United States Constitution, which, respectively, state that "no person shall ... be deprived of life, liberty, or property without due process of law," and that "no state shall ... deny to any person within its protection the equal protection of the laws." In virtually all cases, however, there 


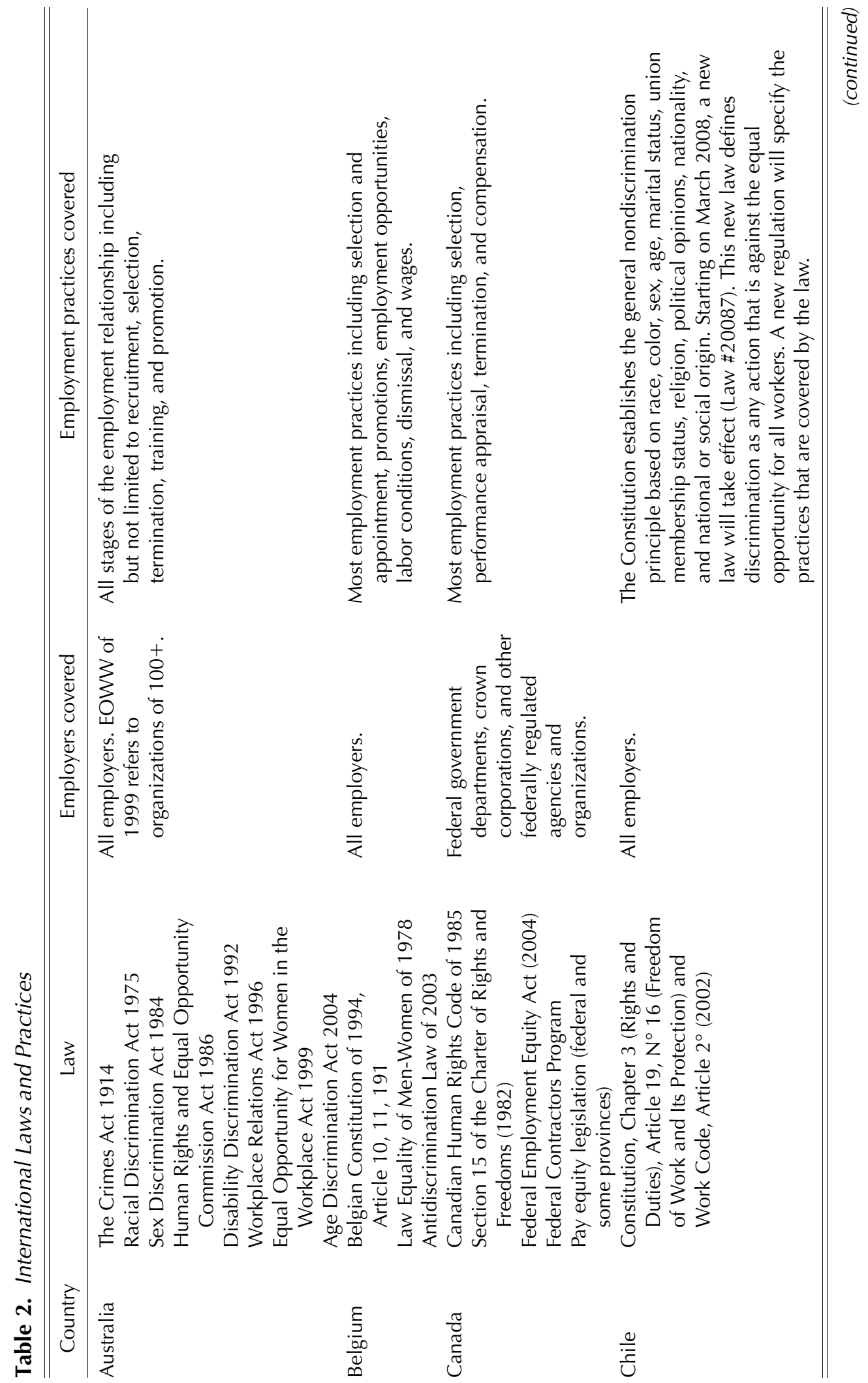




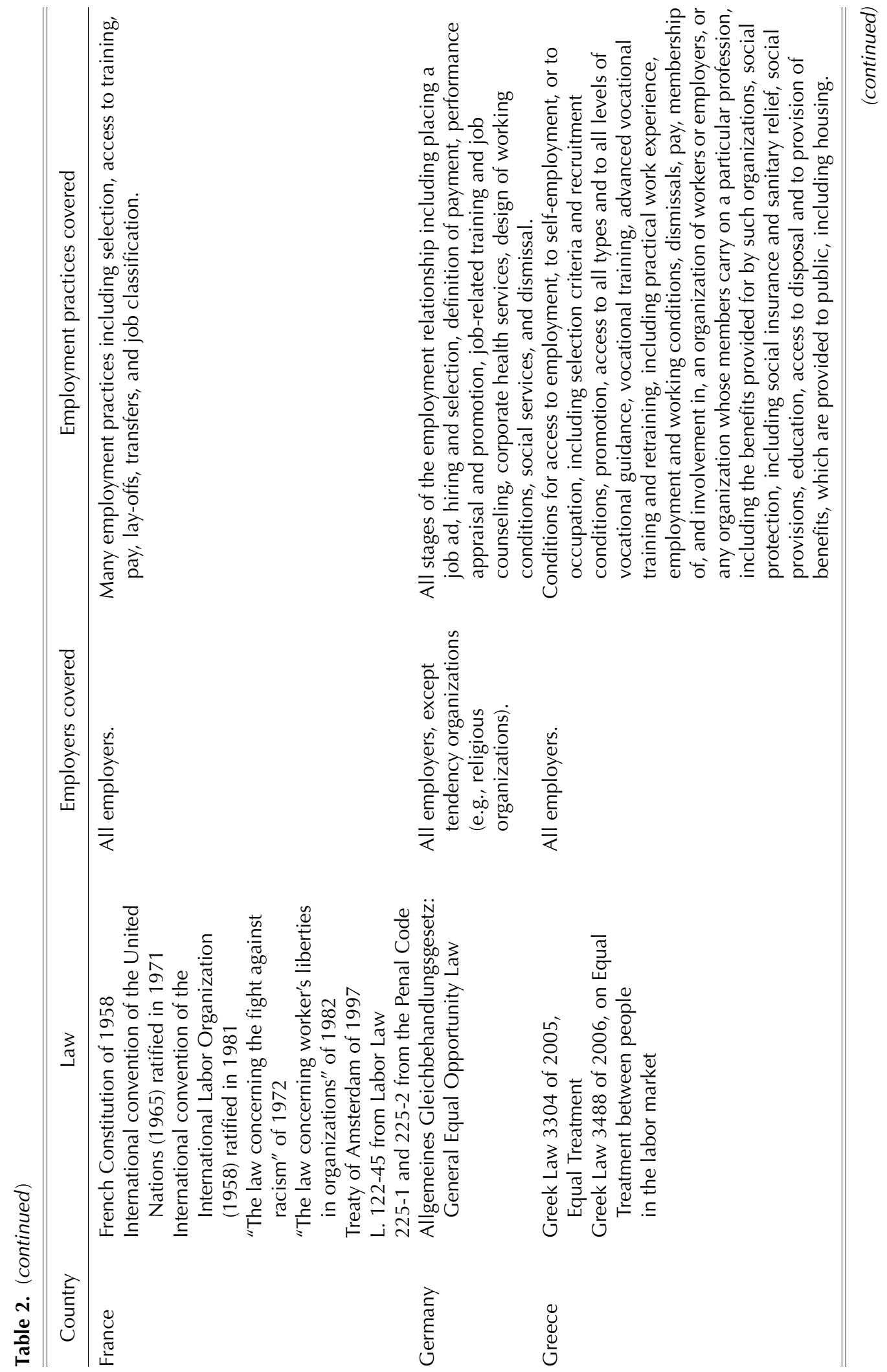




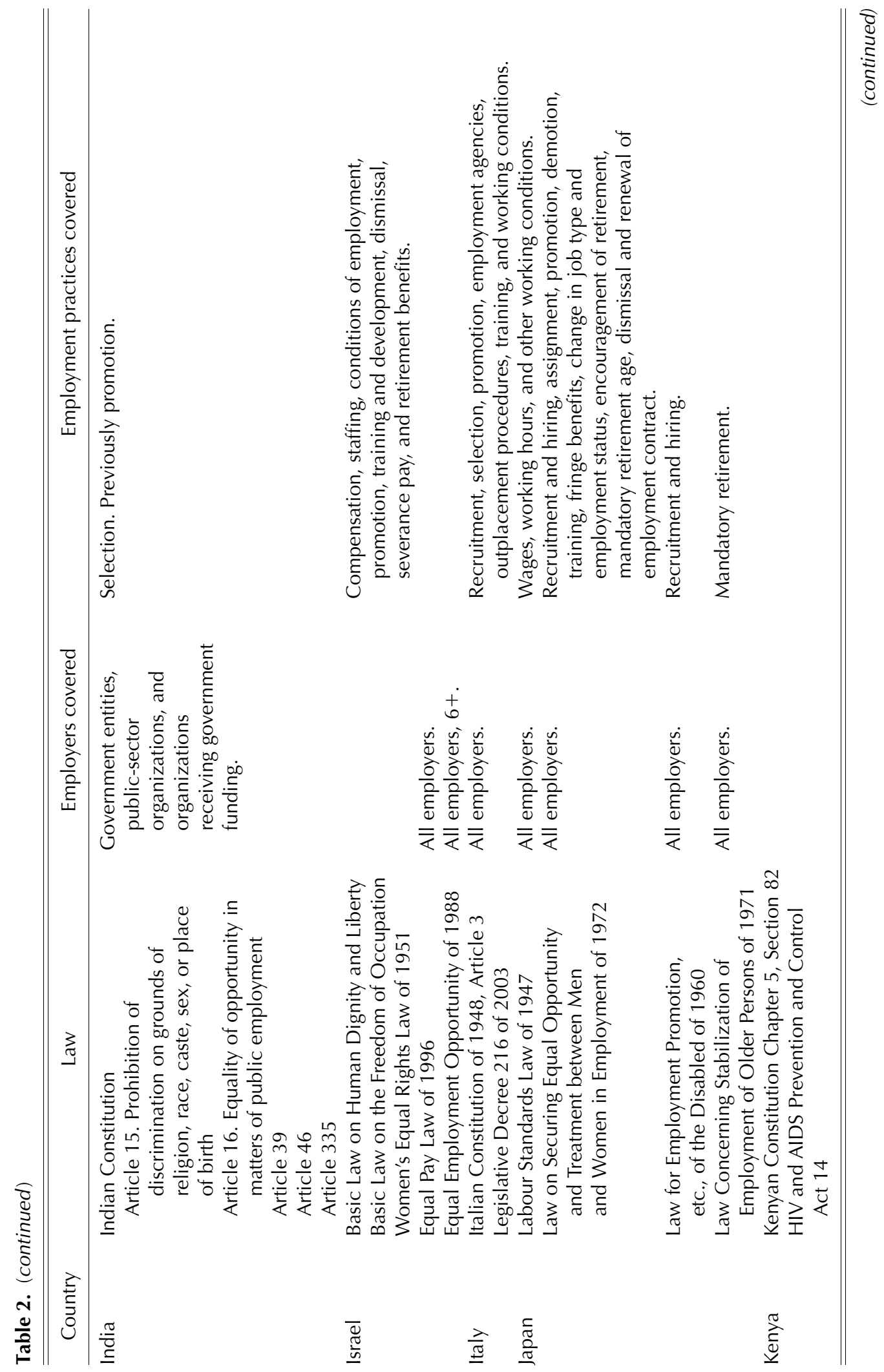




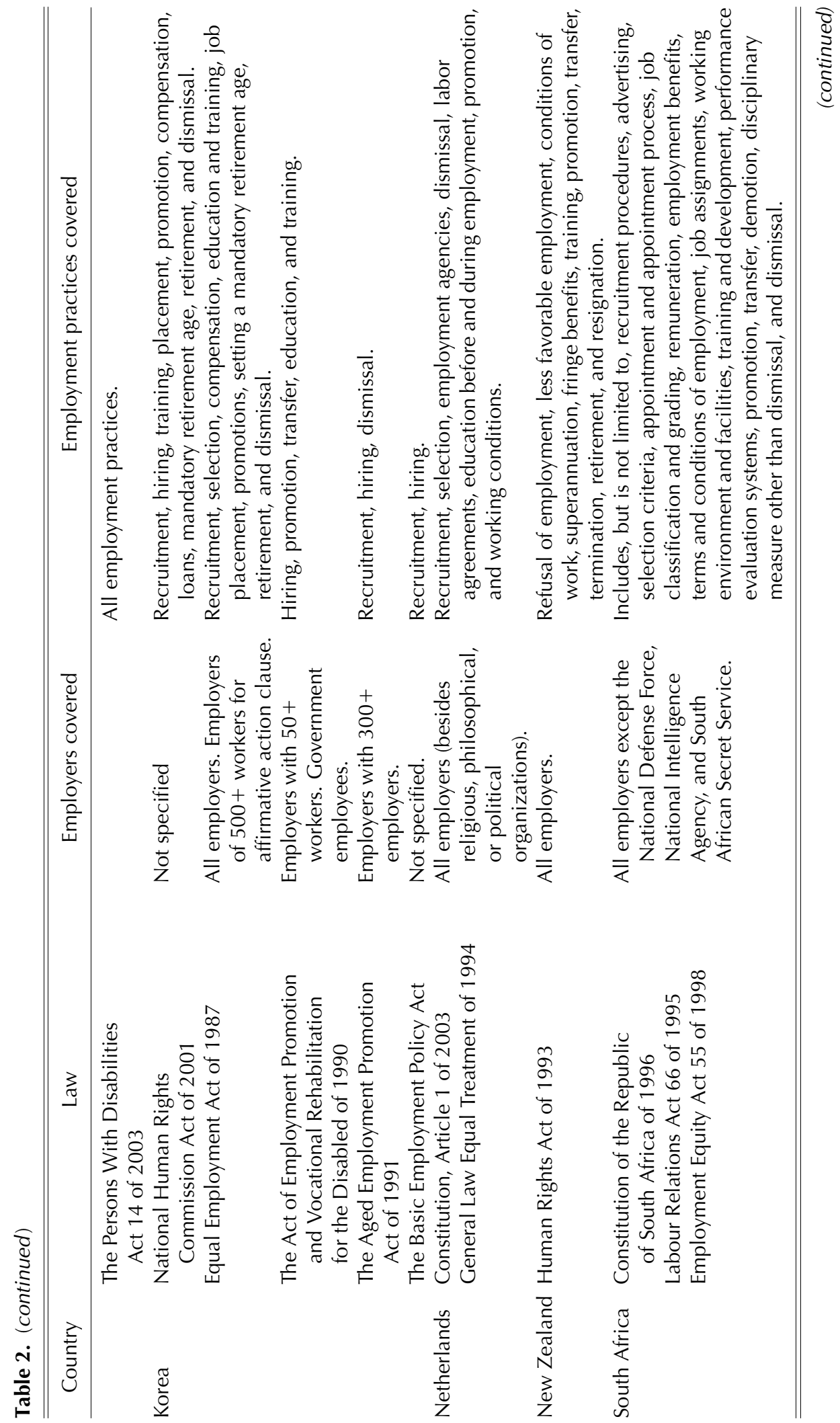




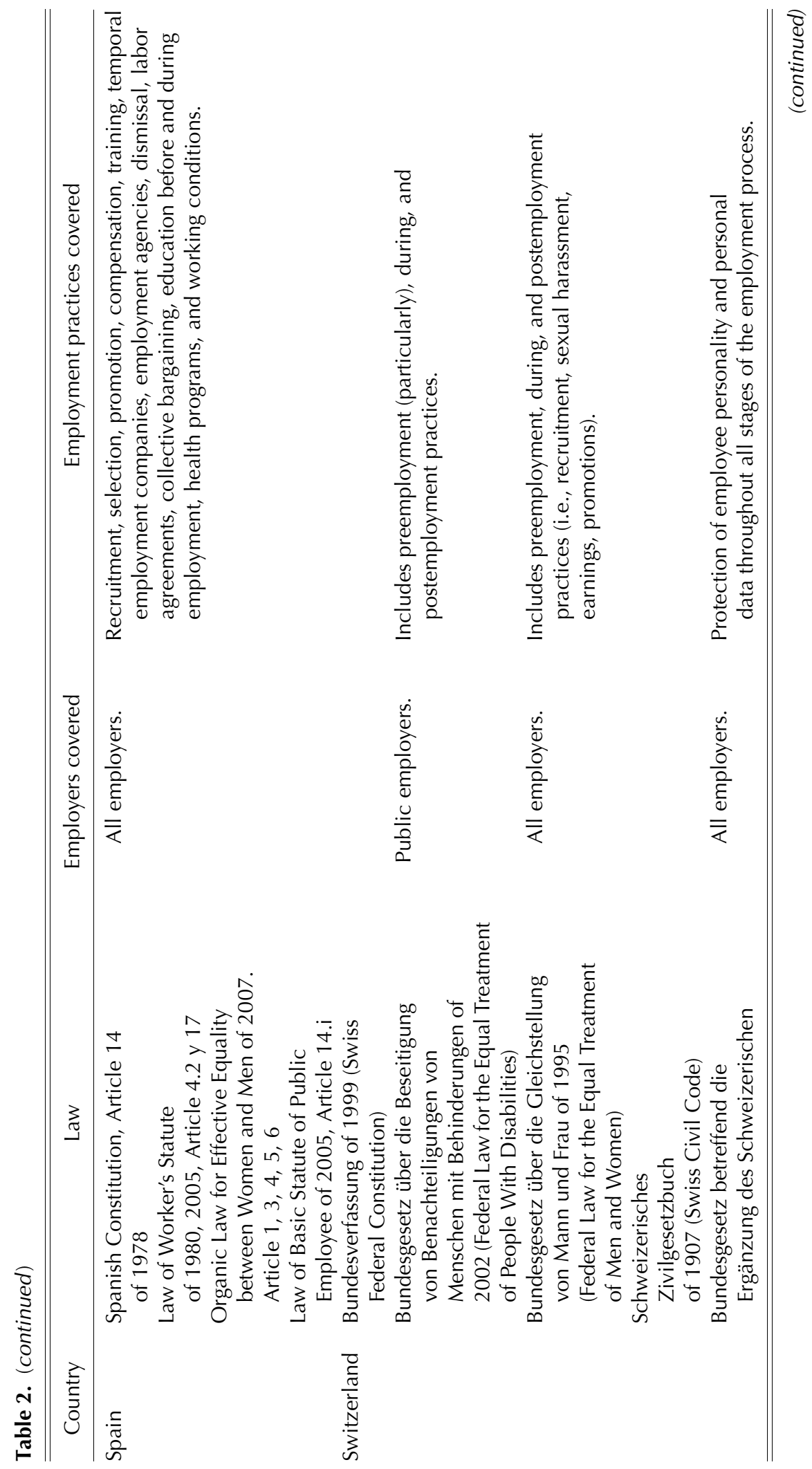




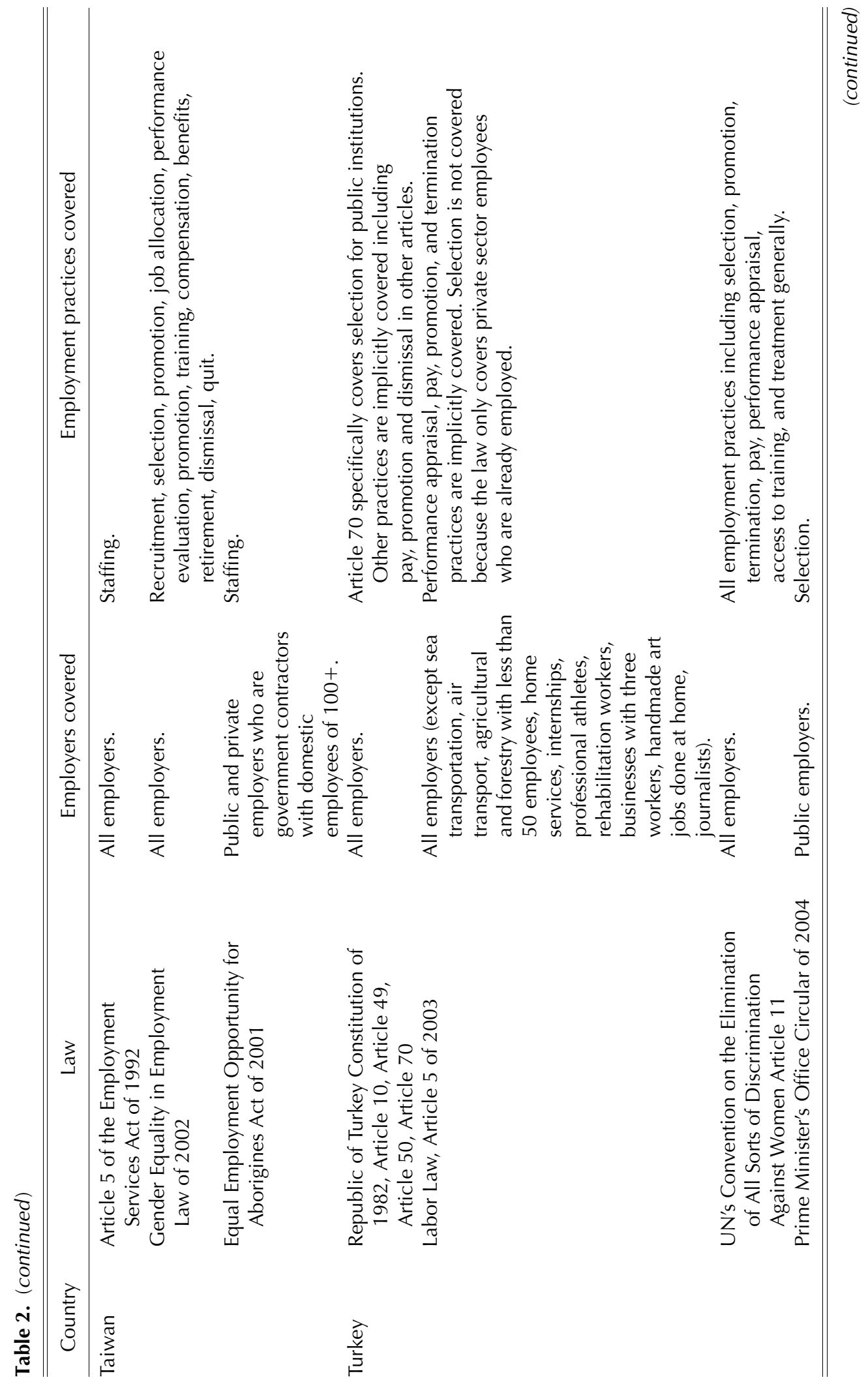




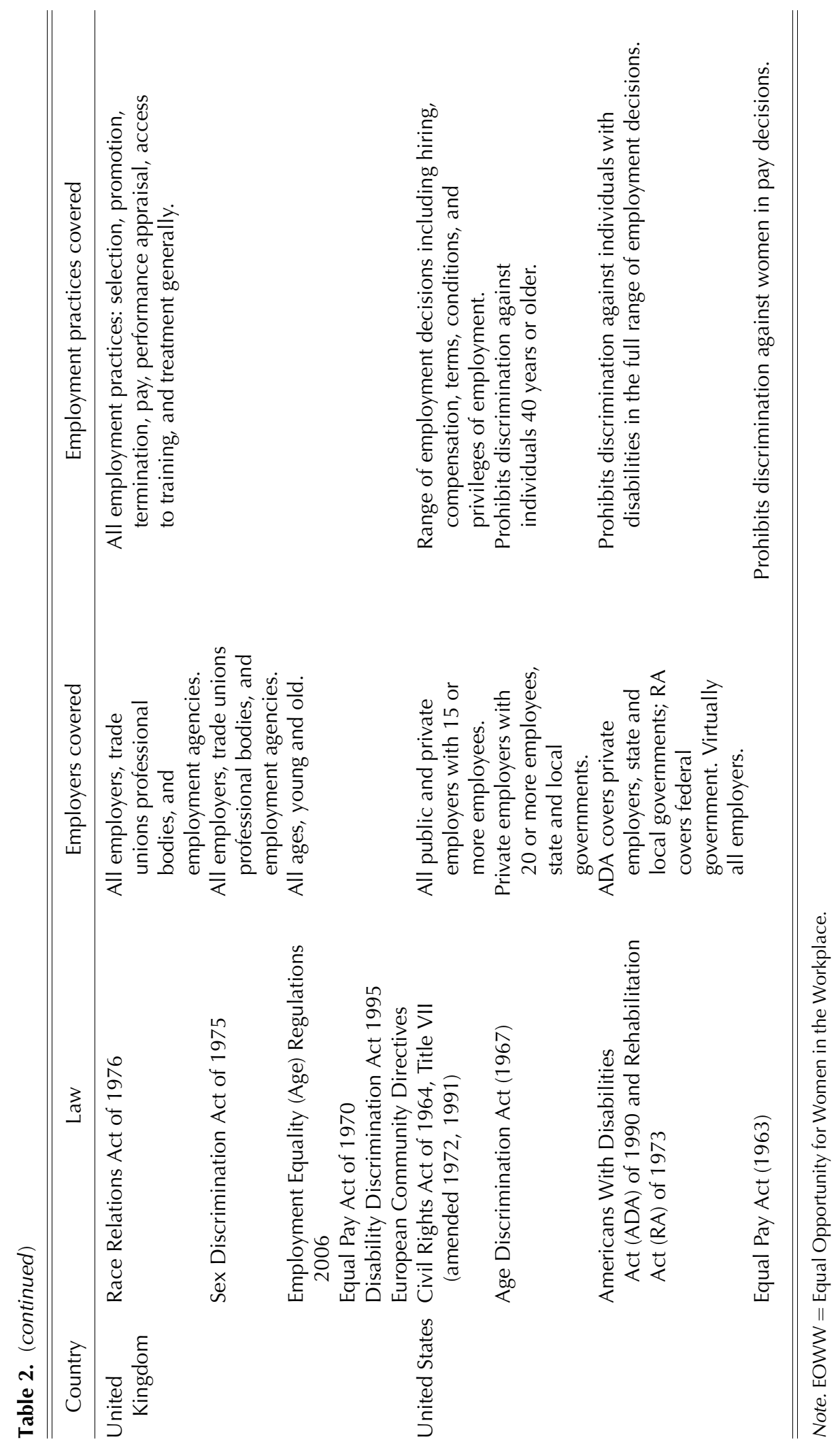


are also specific laws defining specified protected classes, specific covered employment practices, and specifying which employers are covered. The intent here is to identify the major contemporary federal laws and government decrees, and as such is not a complete record of all historical employment regulations. For example, in the United States, a specialist can rightly note that Civil Rights Acts of 1866 and 1871 are still relied upon on occasion, though these are not listed in the table. Also, a number of states and cities have additional statutes, offering protection to groups beyond those covered by federal law.

Second, the protections offered are generally quite sweeping in terms of the types of employers covered. In most cases, all employers are covered. Some laws are restricted to government employees, and in some cases, coverage is restricted to larger employers, with the coverage threshold varying quite widely for some statutes (e.g., more than 6 employees in Israel, 15 in the United States, 100 in Taiwan, 300 in Korea).

Third, it is typical for a broad range of employment practices to be included. Employee selection is specifically included in all countries, except Chile, which has the least developed set of employment rights regulations of the countries examined here and which has yet to specify a set of covered employment practices. However, Chile does prohibit discrimination based on race, color, sex, age, marital status, union membership, status, religion, political opinions, nationality, and national or social origin in its Constitution but does not specify which specific employment practices are covered.

Fourth, there is both considerable commonality and considerable variation in the classes, which receive protection in each country. Table 3 identifies the most common protected classes and indicates whether those classes are covered in each of the contributing countries. The classes covered in U.S. Civil Rights law emerge as widely and commonly covered across countries: race, color, religion, gender, national origin, age, and disability status. Three categories not protected by federal statute in the United
States are protected in a majority of countries: political opinion, sexual orientation, and marital/family status. A number of protected classes are covered in only a small number of countries or are unique to a small number of countries; Table 4 identifies these less common protected classes. Examples include language, physical appearance, union membership, socioeconomic status, and HIV status.

\section{Question 4}

What is required as prima facie evidence of discrimination? What is required to refute a claim of discrimination?

In the vast majority of countries, both direct (e.g., differential treatment) and indirect (e.g., disparate impact) prima facie evidence of discrimination are acknowledged. In India, disparate impact is necessary but not sufficient to prove a case of discrimination; underrepresentation must be shown to be because of historical social or religious discrimination toward a particular group. Only two countries require evidence of the intent to discriminate, Taiwan and Turkey, thus ruling out a disparate impact theory of discrimination.

However, although disparate impact evidence can be used as evidence in most countries, highly specific evidentiary rules used in the United States (e.g., the four-fifth rule and tests of the statistical significance of the difference between passing rates for various groups) are generally not in use (Canada is an exception, as cases using the four-fifth rule in the United States have been used to make a case for a similar standard). Commentators note that in most cases, there are few or no cases involving disparate treatment challenges to predictors commonly used by psychologists, and thus, there is not the extensive case law that has developed in the United States. Recall that the four-fifths rule in the United States derives from guidelines issued by enforcement agencies and the use of significance testing derives from case law; neither the concept of disparate impact nor the mechanisms for identifying its presence is contained in statute. Absent a history of challenges resulting 
Table 3. Most Common Protected Classes

\begin{tabular}{|c|c|c|c|c|c|c|c|c|c|c|}
\hline \multirow[b]{2}{*}{ Country } & \multicolumn{10}{|c|}{ Common protected classes } \\
\hline & Race & Sex & $\begin{array}{l}\text { National/ } \\
\text { ethnic } \\
\text { origin }\end{array}$ & Color & Age & Religion & Disability & $\begin{array}{l}\text { Political } \\
\text { opinion }\end{array}$ & $\begin{array}{c}\text { Sexual } \\
\text { orientation }\end{array}$ & $\begin{array}{c}\text { Marital/ } \\
\text { family } \\
\text { status }\end{array}$ \\
\hline Australia & $X$ & $X$ & & & $X$ & & $X$ & $X$ & $X$ & $X$ \\
\hline Belgium & $x$ & $x$ & $x$ & $x$ & $X$ & $X$ & $x$ & $X$ & $X$ & $X$ \\
\hline Canada & $X$ & $x$ & $X$ & $x$ & $X$ & & $x$ & $X$ & $X$ & $X$ \\
\hline Chile & $x$ & $x$ & $x$ & $x$ & $x$ & $x$ & & $x$ & & $X$ \\
\hline France & $x$ & $x$ & $x$ & & $X$ & $x$ & $X$ & $X$ & $x$ & $x$ \\
\hline Germany & $x$ & $x$ & $x$ & & & $x$ & $X$ & & $X$ & \\
\hline Greece & $x$ & & $X$ & & $X$ & $x$ & & & $X$ & \\
\hline India & & $x$ & & & & & $x$ & & & \\
\hline Israel & $x$ & $x$ & $x$ & & $x$ & $x$ & & $x$ & $x$ & $x$ \\
\hline Italy & $x$ & $x$ & & & $X$ & $X$ & $X$ & $x$ & $x$ & \\
\hline Japan & & $x$ & $X$ & & $X$ & $X$ & $x$ & $X$ & & \\
\hline Kenya & $x$ & $x$ & $X$ & $x$ & & $X$ & $X$ & $x$ & & \\
\hline Korea & $x$ & $x$ & $x$ & $x$ & $X$ & $x$ & $X$ & $X$ & $X$ & $x$ \\
\hline Netherlands & $x$ & $x$ & $x$ & & $X$ & $x$ & $X$ & $X$ & $X$ & $x$ \\
\hline New Zealand & $x$ & $x$ & $X$ & $X$ & $X$ & $x$ & $X$ & $X$ & $X$ & $x$ \\
\hline South Africa & $x$ & $x$ & $X$ & $x$ & $X$ & $x$ & $X$ & $x$ & $x$ & $x$ \\
\hline Spain & $x$ & $X$ & $x$ & & $x$ & $x$ & $x$ & $x$ & $x$ & $x$ \\
\hline Switzerland & $x$ & $x$ & $x$ & & $x$ & $x$ & $X$ & $x$ & & \\
\hline Taiwan & $x$ & $x$ & $x$ & & & $x$ & $x$ & $x$ & & $x$ \\
\hline Turkey & $x$ & $x$ & & $x$ & & $x$ & & $x$ & & \\
\hline United Kingdom & $x$ & $X$ & $X$ & $x$ & $X$ & & $X$ & & & $x$ \\
\hline United States & $x$ & $x$ & $x$ & $x$ & $X$ & $x$ & $X$ & & & \\
\hline
\end{tabular}

in case law, it is not surprising to see the lack of specificity as to evidentiary standards.

A similar lack of specificity applies to the question of what is required to refute a claim of discrimination. Table 5 summarizes information across countries. In general, there is some version of the shifting burden of proof model in countries where disparate impact evidence is permissible. After a prima facie showing, the burden to justify the use of the employment practice shifts to the employer in all countries except Switzerland, where the burden of showing that the practice is not job related is only partially reduced or remains with the plaintiff. There is a general notion that the employer should present evidence to support the job relatedness of the employment practice in question, but rarely is the required form of such evidence specified. The identification of validity evidence as a mechanism for establishing job relatedness is rare.

\section{Question 5}

What are the consequences of violation of the laws?

Table 5 summarizes possible consequences of violation in each participating country. There is considerable variation in the array of possible remedies. As a point of reference, note that in the United States, the focus is on compensatory or "make-whole" remedies, with punitive damages reserved for instances of intentional discrimination. Similarly, make-whole remedies are part of the landscape in all countries for which information could be obtained. Several countries also provide fines and punitive damages (e.g., Switzerland, Turkey), and several include 
Table 4. Other Protected Classes by Country

\begin{tabular}{|c|c|}
\hline Country & Other protected classes \\
\hline Australia & $\begin{array}{l}\text { Breastfeeding, family or career responsibilities, irrelevant criminal record, } \\
\text { physical features, potential pregnancy, trade union or employer association } \\
\text { activity, sexual harassment, and pregnancy and transgender status }\end{array}$ \\
\hline Belgium & $\begin{array}{l}\text { Union membership, membership of other organizations, health, and any other } \\
\text { personal characteristic }\end{array}$ \\
\hline Chile & Union membership status \\
\hline France & $\begin{array}{l}\text { Moral principles, genetic characteristics, union activities or activities in a } \\
\text { "mutuelle," physical appearance, family name, and health }\end{array}$ \\
\hline Germany & Philosophy of life and sexual harassment \\
\hline India & Scheduled castes, scheduled tribes, and other backward classes \\
\hline Israel & Personal status and military service \\
\hline Italy & Personal and social conditions and language \\
\hline Japan & Social status \\
\hline Kenya & Tribe, local connection, and HIV/AIDS status \\
\hline Korea & $\begin{array}{l}\text { Social status, region of birth, appearance, criminal record after punishment has } \\
\text { been served, academic background, medical history, pregnancy, and } \\
\text { physical conditions (e.g., appearance, height, weight) }\end{array}$ \\
\hline Netherlands & Philosophy of life, chronic disease, full-/part-time work, and type of contract \\
\hline New Zealand & Ethical belief, employment status, and sexual and racial harassment \\
\hline South Africa & HIV status, conscience, belief, culture, birth, pregnancy, and language \\
\hline Spain & Social condition and membership to a labor union \\
\hline Switzerland & Socioeconomic status, way of life, and language \\
\hline Taiwan & $\begin{array}{l}\text { Thought, provincial origin, appearance, facial features, union membership, } \\
\text { status, and language }\end{array}$ \\
\hline Turkey & Philosophical belief, sect, and language \\
\hline United Kingdom & Persons who have undergone gender reassignment or intend to \\
\hline United States & Pregnancy \\
\hline
\end{tabular}

imprisonment as a possible consequence (e.g., Belgium, France, Greece).

\section{Question 6}

Are particular selection methods limited or banned as a result of legislation or court rulings?

There are relatively few restrictions on specific selection methods. As a point of reference, U.S. law regulates the use of the polygraph, prohibiting its use for most private employers; several other countries restrict polygraph use as well (e.g., Germany, Israel, Turkey). The only selection method specifically mentioned in U.S. law is the reference in the Tower amendment to Title VII of the Civil Rights Act of 1964 to the permissibility of professionally developed ability tests, provided that such tests are not designed, intended, or used to discriminate. Additional instances reported of restrictions on specific selection methods in participating countries include a prohibition against comprehensive personality assessment in Switzerland and a restriction on the use of certain Minnesota Multiphasic Personality Inventory (MMPI) and California Psychological Inventory (CPI) items in Spain.

The most strikingly different approach to regulating selection practices is found in South Africa. Rather than the common approach of a presumptive right of an employer to use a particular method absent a successful challenge by a plaintiff, South African law puts the burden immediately on the employer. According to the EEA of 1998, psychological testing and other similar assessments are prohibited unless the test is proven to be scientifically valid and reliable, 

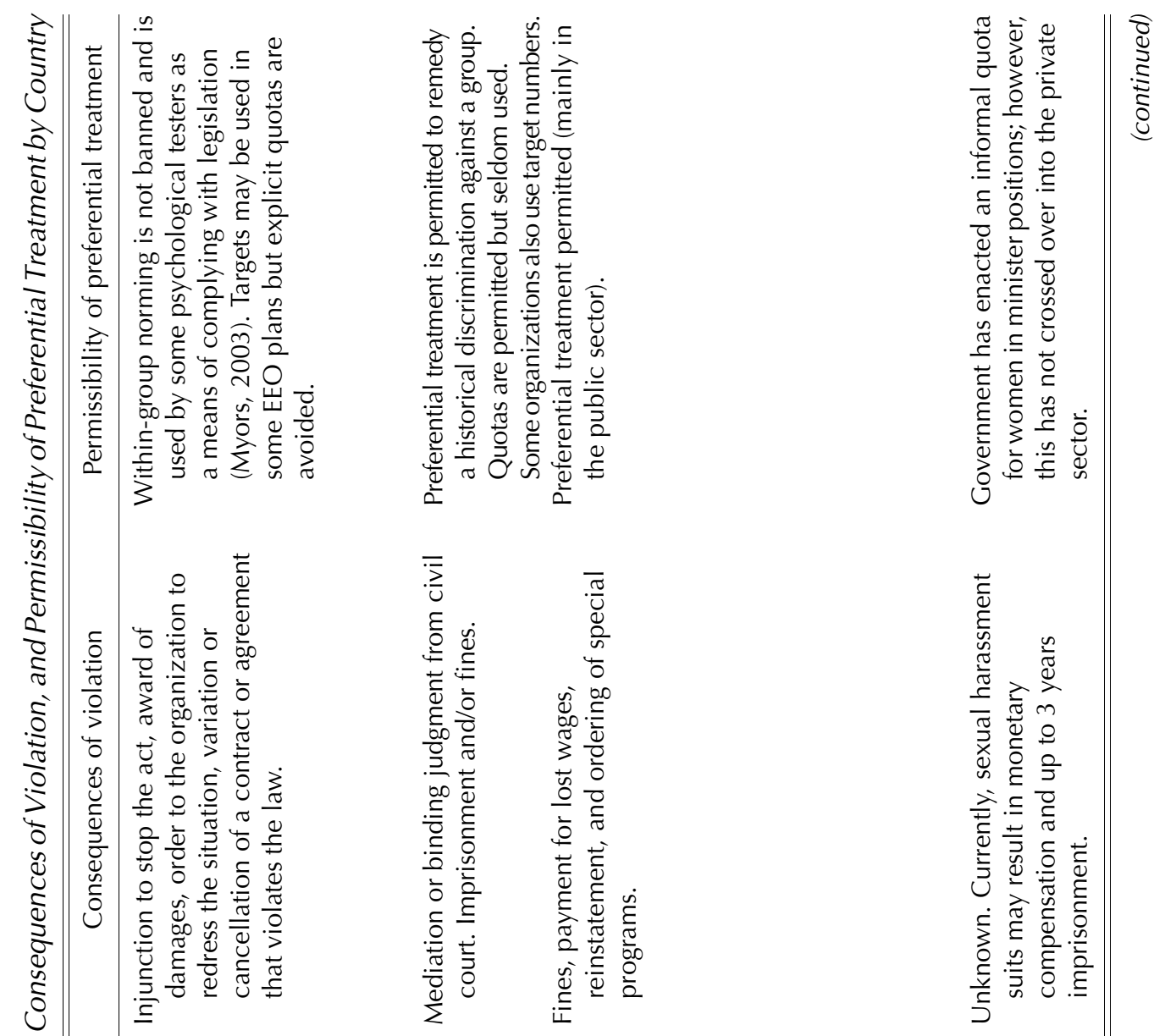

$\frac{0}{\sqrt[0]{2}}$

$\frac{\mathrm{d}}{\mathrm{O}}$

ป气

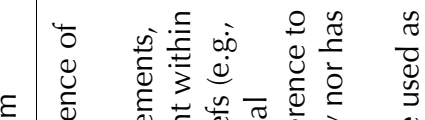

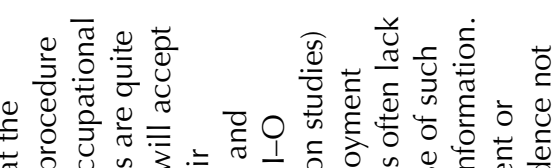

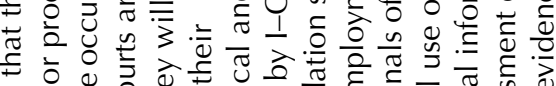

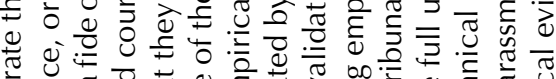
ฮั

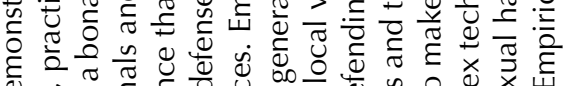

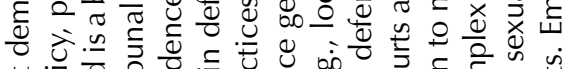

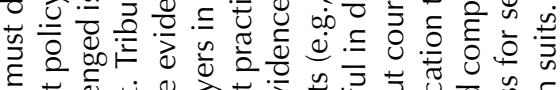

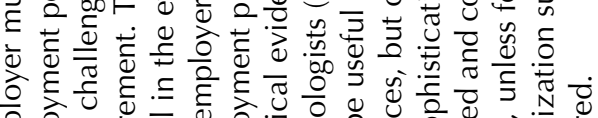

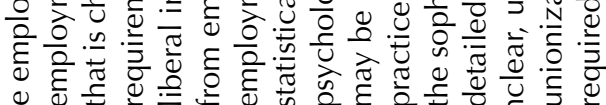
$\stackrel{\cup}{\models}$

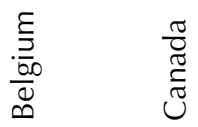

$\frac{0}{\frac{1}{U}}$ 


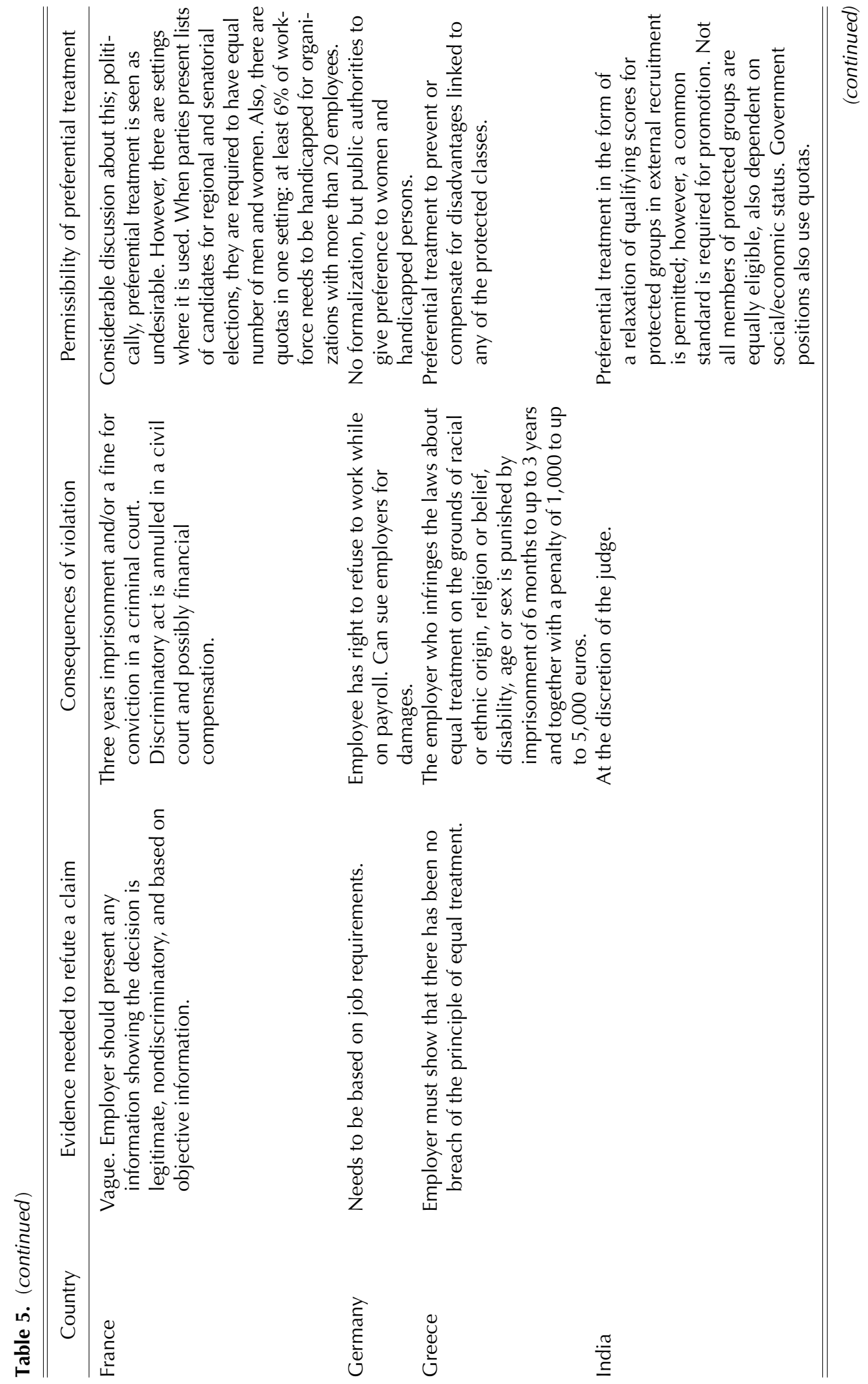




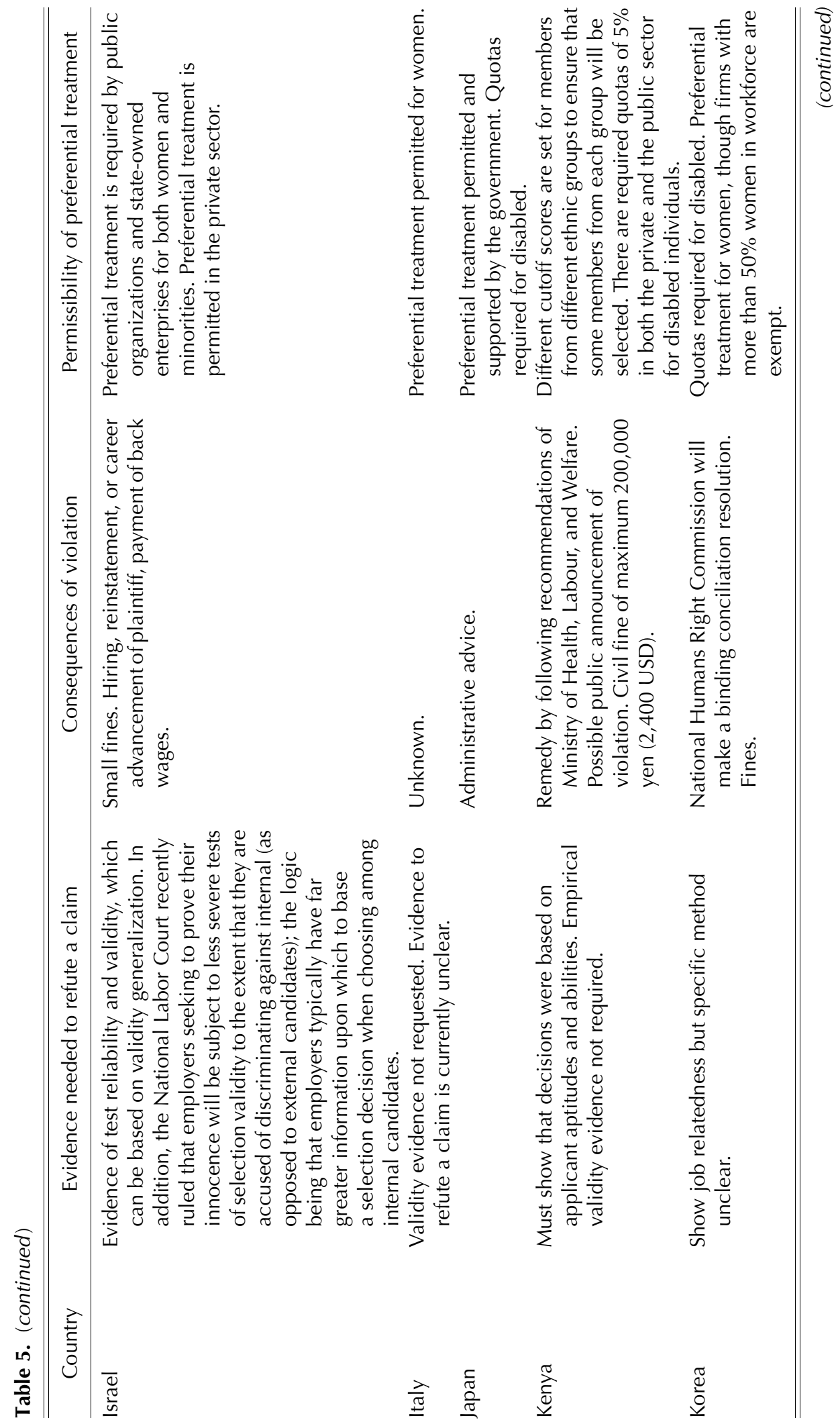




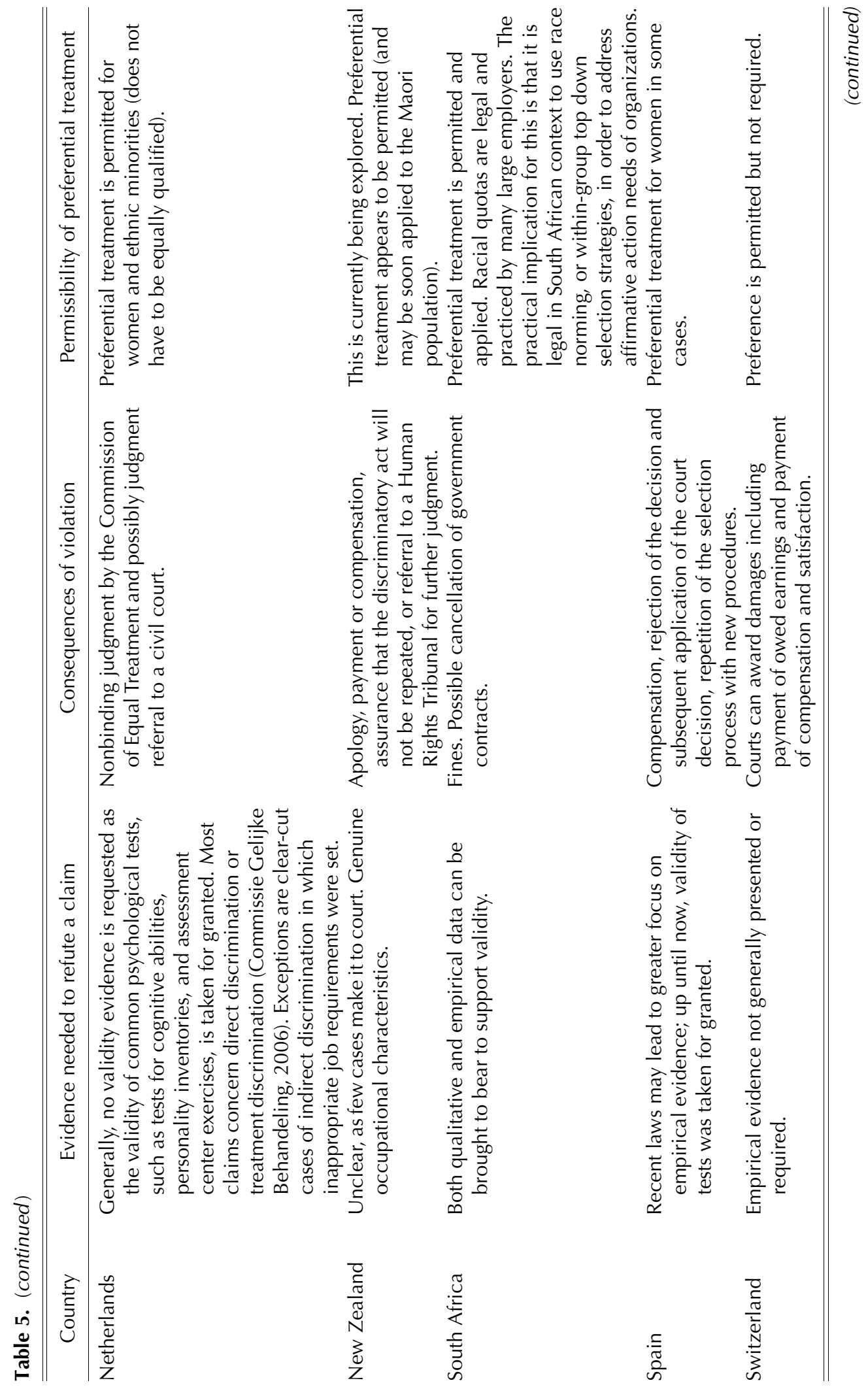




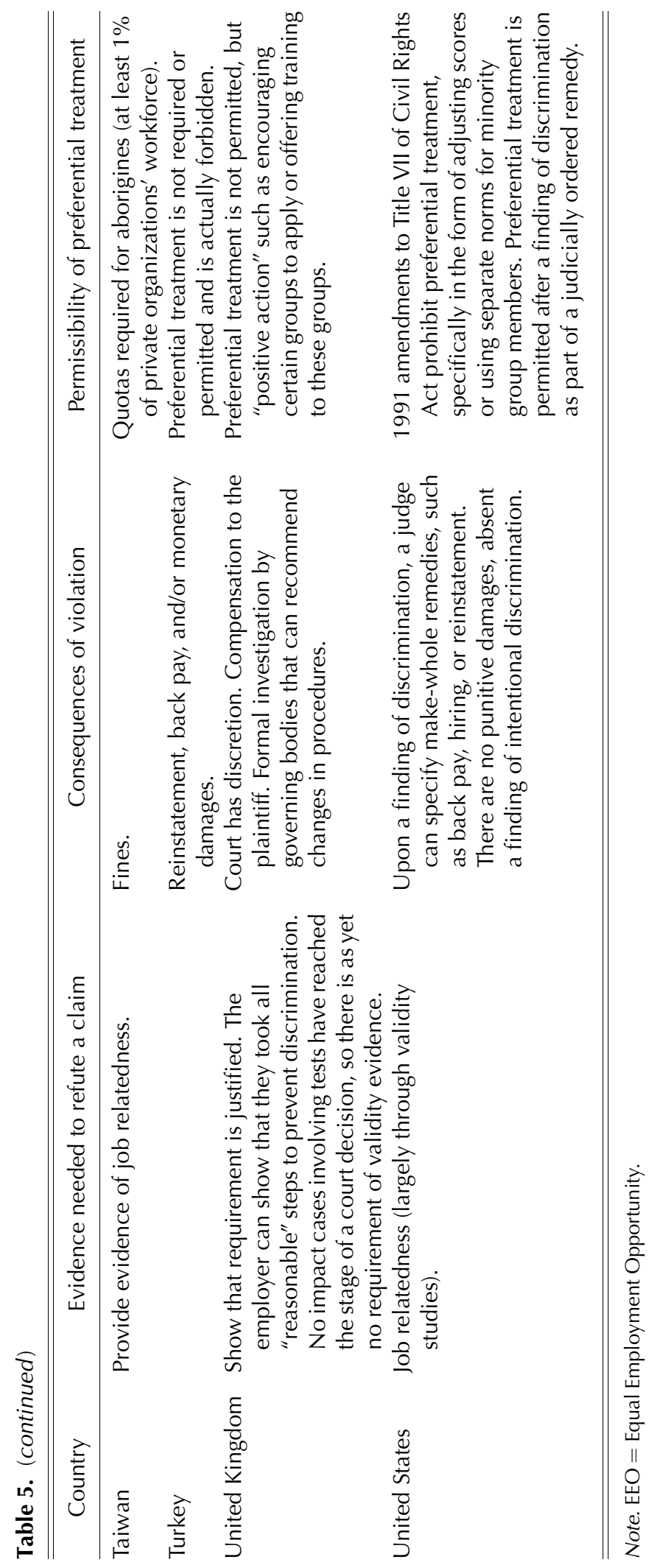


can be applied fairly to all employees; and is not biased against any employee or group. The Society for Industrial and Organizational Psychology in South Africa (SIOPSA) published Guidelines for the Validation and Use of Assessment Procedures for the Workplace during 2005 to provide guidelines for practitioners in the field of I-O psychology to ensure that their assessment instruments and practices comply with the scientific requirements and international best practices (SIOPSA, 2005). These guidelines were largely based on the American Society for Industrial and Organizational Psychology (SIOP) guidelines.

\section{Question 7}

What is the legal status of preferential treatment of members of minority groups (e.g., quotas or softer forms of preference)?

To set the stage, note that the term "affirmative action" is used in a variety of contexts, only some of which involve preferential treatment for protected groups. Some forms of affirmative action involve outreach efforts to publicize openings and to encourage applications from members of protected groups. However, there is no preferential treatment given once an individual is in the applicant pool. Approaches involving preferential treatment fall into two main classes: (a) those which set differing standards for protected and nonprotected groups without setting aside a specified number or proportion of openings for members of protected groups (e.g., using different cutoff scores, using within-group norming) and (b) quota approaches that set aside a fixed number or proportion of openings for members of protected groups.

Table 5 summarizes the status of preferential treatment in the participating countries. Preferential treatment is a domain in which the United States emerges as a clear outlier. Preferential treatment in terms of differing score cutoffs or separate norming of tests within group is prohibited by the U.S. Civil Rights Act of 1991, and the use of quotas is restricted to very limited settings, such as a court-ordered remedy following a find- ing of discrimination. In contrast, in only two countries do commentators report a prohibition against minority preference (Turkey and the United Kingdom). The types of preference permitted, and the settings in which it is used, do vary widely. The status of quotas varies from prohibited (Australia), to permitted but rarely used (Belgium), to permitted and widely used (South Africa), to used in government sectors (backward classes in India and women in Chile), to required for certain groups (e.g., aborigines in Taiwan, individuals with disabilities in France, Japan, Kenya, Korea). Several commentators note that applying lower standards to protected groups (e.g., different cutoffs or withingroup norming) is used (Australia, India, South Africa). In India, lower qualifying scores for protected groups are permitted for external selection but not for promotion.

\section{Question 8}

How have laws and the legal environment affected the practice of I-O psychology in this country?

Below are brief observations from each country regarding the nature of selection practices and the role of the legal environment in driving these practices.

Australia. I-O psychological practices such as job analysis, empirical validation, and criterion development have not been directly affected by the legal environment. Employers have not shied away from particular tests but are very mindful of job relevance and fairness. Controversial methods like polygraphs, drug and genetic testing, and graphology are not used. Best practice is promoted more through the impact of international firms operating within Australia, trade journals and local management schools, and I-O programs promoting findings from the international research literature. Note that trade unions have historically been strong. Unions have typically emphasized workplace equity and diversity and have been suspicious of any $\mathrm{I}-\mathrm{O}$ practices seen to mainly advantage management, such as psychological testing and performance 
appraisal while being supportive of practices like training, which were seen to be in line with both worker and management interests.

Belgium. As a result of the quasi-legal framework in Belgium, employers are free to use any method of their choice. In practice, good public relations and social concerns over fairness weigh heavily in companies' concerns and have led most larger organizations toward using popular and mainstream predictors generally (interviews, cognitive tests, personality inventories, work samples, and so forth).

Canada. Human rights and employment equity legislation have had a pervasive effect on the practice of I-O psychology in Canada. These legal trends have led at least some employers, especially in the largest organizations such as public service and the military, to formalize and standardize their employment practices to a greater extent with the help of $\mathrm{I}-\mathrm{O}$ psychologists and other human resource management professionals. This trend will likely continue over at least the next few decades.

Chile. Prior to March 2008, there were no laws concerning workers' rights before they are hired. At that point, a new law took effect (Law \#20087). This new law defines discrimination as any action that is against the equal opportunity for all workers. A new regulation will specify the practices that are covered by the law. However, because of the new law concerning workers rights, the demands from workers for fairer procedures and the organizations' requests for more effective and efficient systems, I-O psychology is slowly but steadily giving more importance to practices such as job analysis, criterion development, empirical validation, and the general evaluation of all selection methods and procedures. Most companies use multiple predictors (interviews, personality, intelligence tests). The interview is typically given more importance. The use of projective techniques such as Rorschach or Thematic Apperception Test (TAT) is quite common.
France. Concerns of discrimination and explicit efforts to combat it have only recently received a great deal of attention in France, notably with the creation in 2004 of the HALDE ("Haute Autorité de Lutte contre les Discriminations et pour l'Egalité": High Authority for the Fight against Discriminations and for Equality). Many of the suggested measures, including using job analysis and "relevant" selection methods, have only recently been publicized in these efforts, and psychologists do not appear to have played a major role in these efforts, although it is clear that our competencies have an important potential contribution for these questions.

Germany. In the 1970s and 1980s, there was strong opposition to personnel selection. These reservations are still present, but in general, attitudes are continuously shifting toward empirical selection procedures. The "Allgemeines Gleichbehandlungsgesetz" influenced many companies and corporations to reflect on their standards of job advertisements and personnel selection. Since the law has been in place, many training programs are offered to help companies protect themselves from discrimination and its corresponding lawsuits. Human resource departments are more precisely formulating their hiring standards (e.g., by job analysis) and are beginning to more widely use psychological preemployment testing (e.g., via Internet resources) rather than application materials provided by the applicants.

Greece. The profession of I-O psychology in Greece is still in its infant stage. As a result, there are only a few practitioners and academics in the field. Most of the practitioners work in human resources departments of large private, local, and multinational firms. As a result, the legal environment has not really taken any steps in relation to various $\mathrm{I}-\mathrm{O}$ practices. Recruitment and selection procedures have only recently started becoming more "objective," and more advanced recruitment and selection tools and methods (e.g., psychometric testing, assessment centers) have recently been introduced in the private sector. The vast majority of firms employ fewer than 
100 people. Therefore, most employers still prefer the use of more traditional techniques, such as references.

India. The field of I-O psychology is still not fully developed in India. Psychological assessment as a part of personnel selection is not widely practiced. It is still an emerging field, and as such, laws do not contain any guideline to the tools and techniques of $\mathrm{I}-\mathrm{O}$ psychology. Psychological assessment as a part of personnel selection has been in practice mainly in the armed forces. But in other areas, this has been a recent development. Even though psychometric testing has been recently introduced in recruitment/ selection in various private-sector enterprises, the tests that are used are sometimes not properly validated. Test selection is not often done after a proper job analysis. Selection tests mainly assess knowledge and skill and not cognitive abilities and personality.

Israel. Though the legal environment stemming from the enactment of the Equal Employment Opportunity (EEO) Law in 1988 (and its amendments in 1992 and 1995) has had an important effect on HR practice in Israel, it is difficult to attribute the advances in the practice of I-O psychology strictly to such legal changes. Indeed, given the fact that until recently, the burden of proof was primarily with the plaintiff, and the fact that penalties were and remain quite low, the legal environment has provided employers with little incentive to transform often-discriminatory HR practices. Although various I-O practices (e.g., job analysis, empirical validation) have become far more common in Israeli enterprises in recent years, it is likely that much of this change is institutional in nature, with such practices adopted from the growing number of hightechnology American firms operating in Israel, most of which enact such practices in their Israeli subsidiaries as part of a global, commitment-oriented HR strategy (Bamberger \& Meshulam, 2000).

Italy. To date, a strong legislative framework for antidiscrimination has not devel- oped. There is a laissez-faire political attitude toward all minority groups (and women) regarding the work context. Practitioners in I-O psychology must follow an ethical code based on Italian legislation concerning workers and legislative decrees on positive action regarding women at work; direct and indirect discrimination; and the use of privacy data in selection, training processes, and work context.

Japan. The legal environment regarding the equal employment opportunities is still in progress in Japan. Also, in general, it is highly costly and time consuming for victims of discrimination to file lawsuits in Japan. Thus, the number of cases regarding the discrimination in selection is relatively small. These situations have not promoted perceived legal risk for employers and the use of more rigorous selection techniques developed in I-O psychology (e.g., job analysis, empirical validation, criterion development).

Kenya. The practice of I-O psychology in Kenya is most evident in the methods used by consulting firms. Nairobi is home to several global consulting companies that are called in by large companies to apply their methodologies to human resource management. With regard to selection, this largely involves the administration of psychological assessment tests. The concerns of managers in employing any method that seemingly favors a given group would be political rather than legal. The weak employment legislation in Kenya clearly biases the legal climate in favor of employers. As in other developing countries, unemployment is a huge problem in Kenya. The supply of labor far exceeds the demand. As such employers usually have several well-qualified candidates vying for a single position.

Korea. It would be fair to say that the legal environment has not affected the practice of I-O psychology in Korea much. Compliance to the discrimination laws especially in the selection phase does not seem to be of major concern to employers in Korea. It is not difficult to find items in application forms that are designed to inquire personal 
characteristics of applicants that are thought to be directly relevant to discriminatory decisions (e.g., age, gender, photo, parents' position, academic backgrounds, religion). The insensitivity of employers to discrimination might come from their perception that the costs they have to bear because of their getting involved in discrimination are not big enough compared to what they have to invest in developing sophisticated I-O practices related to selection.

Netherlands. The Netherlands provides an unusual paradox of a comparatively weak structure of protective legislation for minority groups during selection, a notably protectionist set of employment laws for all once employed (i.e., regardless of ethnic origin, gender, marital status, disability, sexual orientation, or other factors), and an espoused national culture of openness and tolerance politically and socially. As a small country, social regulation and conformity pressure play a far larger role in employer behavior and concerns over fairness in selection. Legal precedent thus takes second priority to social conformity in Dutch recruiter behavior, it can be argued, and a climate of espoused tolerance, openness, and expressed social inclusiveness prevails but is not backed by a developed legislative framework for antidiscrimination. Fears over potential problems posthiring because of the extremely protectionist framework of legal rights for those in employment have rather led to notably cautious practices in employee selection.

New Zealand. At this point, there is little in the law that has had an impact on I-O psychology. Job analysis is rarely conducted, and competency modeling as a pseudomeasure of job validation is highly prevalent in New Zealand. Despite rhetoric to assist Mäori, conducting research showing that selection procedures were unbiased is currently not required. Criterion validity studies inside organizations are also rare, mainly because more than $90 \%$ of New Zealand companies have less than 20 employees. We believe, however, that this situation will eventually change as the number of discrimination cases grows.

South Africa. We find that South African antidiscrimination legislation, to a large extent, followed U.S. legislation trends. There has also been, over the years, a strong U.S. academic influence in I-O psychology in South Africa. It is thus no surprise that the South African I-O psychologist finds very similar challenges to the U.S. psychologist regarding fairness in the workplace. We have also seen typical U.S. and international best practice in terms of ensuring fairness in the workplace implemented in South Africa. Job analysis and the need to be able to demonstrate job relatedness in decision criteria meant that U.S. best practice in the design of selection and decision making systems had a major influence in the practice of South African I-O psychologists. The principle of job analysis has also been adopted in the Codes of Best Practice as issued by the minister of labor. The adoption of the American SIOP Guidelines for the validation and use with minor changes by the SIOPSA is another indication of the strong influence of the United States on South African thinking about fairness in the workplace.

Spain. Until very recently, employment discrimination was not a problem for the private and public organizations in Spain. For this reason, personnel selection practices remained stable for many years. In the past 5 years, because of the strong immigration and the new laws protecting specific groups, the organizations are conscious of this problem. However, like the Netherlands, in general terms, there is a comparatively weak structure of protective legislation for minority groups during selection, a notably protectionist set of employment laws for all once employed (i.e., regardless of ethnic origin, gender, marital status, disability, sexual orientation, or other factors), and an espoused national culture of openness and tolerance politically and socially.

Switzerland. The writers' impression is that the legal environment has had only marginal effects on the practice of $\mathrm{I}-\mathrm{O}$ 
psychology in Switzerland. This may be mainly because of the fact that legal codes are not very specific to the issues in question and are rarely enforced. Lawsuits concerning discrimination within the scope of the selection process are extremely rare and are thus not perceived as a risk by employers. However, employers have become more sensitive to issues of equal opportunities and equal treatment of men and women and people with disabilities since the remittal of the Federal Law for the Equal Treatment of Men and Women and the Federal Law for the Equal Treatment of People with Disabilities and the proliferation of respective law suits.

Taiwan. Taiwanese employers and employees are not as aware of the legal concerns of selection systems as Western countries, and thus, laws have not affected the practice of I-O psychology. In relation to selection methods used, although there exist commonly used tools such as cognitive ability tests, personality tests, interviews, tests on job-required skills (e.g., Japanese proficiency, physical ability), and physical examinations, a small portion of employers use ones that are believed by their chief executives such as physiognomy, horoscope, and graphology. These latter sets of individual tools are less conventional to North American multinational companies in Taiwan and thus are rarely adopted by them.

Turkey. Selection is done primarily based on employee referrals, nepotism, personal networks, resumés, and unstructured and semistructured interviews. Resumés usually include a photo of the applicant. Only some large companies and multinational companies use tests for selection. Most of these tests are not validated for the particular job context that they are used. In Turkey, stateregulated physical and psychological tests for employment can be used by psychologists only under the supervision of a psychiatrist employed in psychotechnic laboratories or centers. Various physical and psychological tests have been used since the 1950s.

United Kingdom. Prior to the legislation outlined above, employers never had to explain or justify selection decisions. The law has made more-but not yet all-employers aware of the need to conduct some sort of job analysis, or at least to have some idea of what they are looking for. Employers have become aware of the need to be more systematic and to keep better records. Virtually, all large employers track applicants through the selection process by gender and ethnicity. Virtually all large employers have codes of conduct for selection and for avoiding discrimination in the workplace. Virtually all large employers provide training in selection or interviewing and often require staff to complete this before getting involved in selection. Some of the very largest employers conduct their own validation research (but generally were doing this before any fair employment laws were enacted). Psychological testing has increased in popularity, but from a previously very low level of use. Some employers do seem wary of tests, especially personality tests, but probably more through conservatism or fear of bad publicity than because of equal opportunities concerns.

United States. The legal environment resulting from the Civil Rights Act of 1964 has had a large effect on I-O psychology. The full range of $\mathrm{I}-\mathrm{O}$ practices related to selection (job analysis, criterion development, test development, validation) have been scrutinized and refined within the profession, and employers are more aware of the need for sound and legally defensible selection systems. There is extensive research on subgroup differences on various types of predictors, on methods of detecting bias and on issues related to ways of using test information (e.g., setting cutoff scores, creating composite of predictors, sequencing predictors), on methods of establishing job relatedness, and on estimating the utility of selection systems. It seems safe to say that the field would be quite different today were it not for fair employment legislation.

Summary. In only a few countries (Canada, South Africa, United States) is the legal environment seen as having a large effect on I-O psychology. It is common to see reports of 
increased use of the tools and techniques of I-O psychology, but the driving forces are more commonly the presence of multinational and consulting firms that import $\mathrm{I}-\mathrm{O}$ techniques into the country. In a great many countries, $\mathrm{I}-\mathrm{O}$ is a small but growing field, which is beginning to influence selection practice but is not the driver of changes in selection practice.

\section{Discussion}

Below we offer 30 broad summary statements about the patterns emerging from the narratives from the various countries.

\section{Disadvantaged Groups}

1. Disadvantaged groups could be divided into four main groups: immigrants or foreign residents, religious minorities, racial/ethnic minorities, and language group minorities (speak different primary language).

2. Many European (especially EU) nations have disadvantaged groups who are immigrants or foreign workers. The groups that are disadvantaged are usually eastern European or African.

3. Many Asian countries also have disadvantaged groups who are immigrants or foreign workers.

4. Many of the racial/ethnic minorities are indigenous people (e.g., Australia, Canada, New Zealand, Taiwan, and United States).

5. Most disadvantaged groups are a relatively small proportion of the population, most below the $20 \%$ "breaking point" specified in research on tokenism (Kanter, 1977).

6. Disadvantaged groups can constitute the majority of the population (e.g., South Africa).

\section{Subgroup Mean Differences}

7. Very few countries have research exploring potential mean differences in cognitive ability, personality, or job performance. In terms of cognitive ability, findings usually favor the advantaged group and/or men.

8. Mean differences between local and immigrant populations are affected by immigration policies. Targeting either high-skill or low-skill immigrants can affect the magnitude and direction of mean differences.

\section{Discrimination Laws}

9. Every country has a law or a directive that prevents discrimination on the basis of sex or race/ethnic origin and many other personal characteristics and beliefs.

10. Most discrimination cases seem to be settled by special commissions and/ or courts rather than by juries (which do not exist in several countries).

11. In many countries, few actual cases are actually filed and/or brought to trial, not because discrimination does not occur but because workers do not understand their rights, are not used to protecting these rights (collectivistic orientation, etc.), or do not see much benefit in going to court.

12. Punishment is usually rather light (e.g., minimal to moderate fine or reinstatement, payment of back wages).

13. Concerns about privacy are very prominent in Europe. Many European countries are so concerned that data on race or gender are not collected.

\section{Making and Refuting a Claim of Discrimination}

14. For many countries, though there are laws in place, there is very little clarity about how to establish discrimination and/or what kind of evidence is required.

15. Intent to discriminate is not required in most countries (exceptions are Taiwan, Turkey, and India).

16. Most discrimination cases are handled on a "case-by-case" basis and are based on treating people differently on the basis of group 
membership (direct discrimination) rather than on a procedure or test that systematically disadvantages a group (indirect discrimination). In most countries surveyed, both are illegal.

17. Few actual cases outside the United States challenging the adverse impact or discriminatory nature of formal tests (cognitive ability or personality) exist, and therefore, most countries do not really use validity evidence to refute discrimination.

18. Most countries do not require validity evidence. In many places, the empirical validity of formal tests (e.g., cognitive ability, personality) is implicitly assumed.

19. Most countries do not use relevant workforce comparisons as a basis for discrimination, though this information is sometimes taken under consideration in certain countries.

20. The evidence to refute a claim of discrimination is usually some qualitative evidence of job relatedness or bona fide occupational requirement.

\section{Minority Preference}

21. Minority preference is permitted (and even recommended) in most countries. This is more likely to be true for women or those with disabilities than for racial groups.

22. It is more common for government entities than for private-sector firms to engage in practices involving preferential treatment.

23. Forms of affirmative action vary, ranging from active recruitment and training of women or racial groups that have been traditionally disadvantaged to lower standards for these groups.

24. Quotas are relatively rare but present in a number of countries, such as India (lower castes), Taiwan (aborigines), Korea and France (handicap), and South Africa (race and gender).

25. Explicitly forbidding preferential treatment is rare (e.g., Turkey).

\section{Specific I-O Tools and Impact on I-O}

26. Generally, tools of the I-O psychology field are not explicitly referenced in laws or in common legal practices (exceptions include South Africa, Switzerland, and the United Kingdom).

27. Generally, although firms are free to use whatever selection methods they desire, large firms tend to be aware of social and business pressures for effective selection.

28. The selection method that is most limited/banned is the polygraph.

29. Selection practice tends to be influenced more by the presence of multinational corporations and consulting firms than by legal pressures (with the exception of United states, Canada, and South Africa).

30. I-O psychology is a relatively new field in many countries with limited but growing influence.

We anticipate the response of "but I work in country $X$, and am bound by one set of laws. What value is there in information about other countries?" We have a number of responses. First, more and more of us do or soon will engage in practice that extends across national boundaries. Second, there is value in extending one's framework beyond the national setting with which one is most familiar. Discovering that the same issue is treated differently elsewhere breaks the mold of viewing a certain set of circumstances inevitable. Third, documenting these differences sets the stages for comparative research asking questions about why certain variations are found. For example, why is preferential treatment not generally permitted and held in such negative popular opinion in the United States and not in many other countries? Why are some groups protected in some countries but not others? Fourth, research on various aspects of selection systems is often implicitly viewed with one country's legal environment in mind. A journal reviewer may reject a manuscript on the grounds that it examines a practice or a technique not legally permitted in the reviewer's country. The recognition that this 
practice is permitted in other settings may lead to a different assessment of the value of that research.

In conclusion, we hope that this compilation of information about perspectives from a wide range of countries is useful to students, researchers, and practitioners around the globe. We encourage international collaborations on other issues of interest to I-O psychologists and hope this project provides a useful model.

\section{References}

ATO Report (Ankara Ticaret Odası Raporu, Report of the Ankara Chamber of Trade). (2006). İssizliğin ve Göçün Coğrafyası [The geography of unemployment and migration]. Ankara, Turkey: Ankara Chamber of Trade.

Attal-Toubert, K., \& Lavergne, H. (2006). Premiers résultats de I'enquête sur l'emploi 2005 [Initial results from the 2005 employment survey] (INSEE Première No. 1070). Paris: INSEE. Retrieved April 15, 2007, www.insee.fr/fr/ffc/ipweb/ip1070/ip1070.pdf

Australian Bureau of Statistics. (2004). Labour force status and other characteristics of migrants. Canberra, Australia: Author.

Australian Bureau of Statistics. (2007). Year book Australia, 2007. Canberra, Australia: Author.

Australian Psychological Society. (2003). Guidelines for the provision of psychological services for, and the conduct of psychological research with, Aboriginal and Torres Strait Islander people of Australia. Melbourne, Australia: Author.

Baldwin-Edwards, M. (2004). Statistical data on immigrants in Greece: An analytical study of available data and recommendations for conformity with EU standards. Athens, Greece: Migration Policy Institute \& Mediterranean Migration Observatory, UEHR, Panteion University.

Bamberger, P., \& Meshulam, I. (2000). Human resource strategy: formulation, implementation and impact. Thousand Oaks, CA: Sage.

Blumen, O. (2007). The performative landscape of going-to-work: On the edge of Jewish ultraorthodox neighbourhood. Environment and Planning D: Society and Space, 25, 803-831.

Blust, R. (1999). Subgrouping, circularity and extinction: Some issues in Austronesian comparative linguistics. In E. Zeitoun \& P. J. K. Li (Eds.), Selected papers from the Eighth International Conference on Austronesian Linguistics (pp. 31-94). Taipei, R.O.C. (Taiwan): Academia Sinica.

Bonifazi, C. (2007). L'immigrazione straniera in Italia. II mulino: Studi e ricerche.

Bourlès, L., \& Courson, J.-P. (2000). Recensement de la population 1999 [1999 census of the population] (INSEE Première No. 749). Paris: INSEE. Retrieved April 15, 2007, www.insee.fr/fr/ffc/docs_ffc/IP749.pdf

Cascio, W. F., \& Aguinis, H. (2005). Applied psychology in human resource management (6th ed.). Upper Saddle River, NJ: Pearson Education.
CBS Statline. (2007). Centraal Bureau voor de Statistiek. Retrieved June 8, 2007, http://Statline.cbs.nl

Central Bureau of Statistic, Israel. (2006). Statistical abstract of Israel. No. 57. Jerusalem: Author.

Chernyshenko, O. S. (2005). Report on psychometric evaluation of the general reasoning test (GRT2) for the New Zealand Police: Measurement equivalence across ethnic and gender groups. Auckland, New Zealand: OPRA Consulting Group.

Commissie Gelijke Behandeling (2006). Gelijke behandeling: Informatie voor werkgever. Retrieved April 15, 2007, www.swz.nl.

Commissie Gelijke Behandeling (2006). Gelijke behandeling: Oordelen en commentaar [Equal treatment: Verdicts and comments]. Oisterwijk, the Netherlands: Wolf Legal Publishers.

Council of Indigenous Peoples. (2002). Yearbook of Taiwanese aborigines statistics. R.O.C. Taipei, Taiwan: Executive Yuan.

Council of Indigenous Peoples. (2005). Aborigines employment report. R.O.C. Taipei, Taiwan: Executive Yuan.

Department of Household Registration Affairs. (2005). Statistical yearbook of Interior. R.O.C. Taipei, Taiwan: Ministry of the Interior.

Dienst Onderzoek en Statistiek Gemeente Amsterdam. (2007). Amsterdam in cijfers 2006 [Amsterdam in figures 2006]. Retrieved June 8, 2007, www.os. amsterdam.nl

Directorate-General of Budget, Accounting and Statistics. (2005a). Labor force utilization report. R.O.C. Taipei, Taiwan: Executive Yuan.

Directorate-General of Budget, Accounting and Statistics. (2005b). Monthly bulletin of manpower statistics. R.O.C. Taipei, Taiwan: Executive Yuan.

Fauroux, R. (2005). La lutte contre les discriminations ethniques dans le domaine de I'emploi [The fight against ethnic discrimination in employment]. La Documentation Française. Retrieved October 10, 2005, http://lesrapports.ladocumentationfrancaise.fr/ BRP/054000466/0000.pdf

Federal Statistical Office, Switzerland. (2006a). Ausländerinnen und Ausländer in der Schweiz: Bericht 2006 [Foreigners in Switzerland: Report 2006]. Neuchâtel, Switzerland: Author.

Federal Statistical Office, Switzerland. (2006b). Statistical data on Switzerland 2006. Neuchâtel, Switzerland: Author

Fontaine, J. R. J., Schittekatte, M., Groenvynck, H., \& De Clercq, S. (2006). Acculturation and intelligence among Turkish and Moroccan adolescents in Belgium. Unpublished manuscript, Ghent University, Belgium.

General Board Employment and Labor Market. (2006). The immigration in Belgium: Numbers, flows and labor market. Brussels, Belgium: Federal Government Agency Employment, Labor and Industrial Relations.

Government of India. (1980). Report of the backward classes Commission. Delhi, India: Government of India Press.

Grieco, E. M., \& Cassidy, R. C. (2001). Overview of race and Hispanic origin: 2000. Retrieved May 12, 2007, www.census.gov/prod/2001 pubs/c2kbr01-1. pdf-2001-04-02.

Guenole, N., Englert, P., \& Taylor, P. (2003). Ethnic group differences in cognitive ability test scores 
within a New Zealand applicant sample. New Zealand Journal of Psychology, 23, 39-54.

Guion, R. M. (1998). Assessment, measurement, and prediction for personnel decisions. Mahwah, NJ: Lawrence Erlbaum.

Immigration Bureau, Japan. (2006). Statistics on number of foreign residents [in Japanese]. Retrieved June 5, 2007, www.moj.go.jp/PRESS/070516-1. pdf

Israel Ministry of Industry and Trade. (2007). Women in the world of work-25 facts Israeli working women [in Hebrew]. Retrieved March 3, 2007, www. moital.gov.il

Japan Institute of Labor Policy and Training. (2007). Labor situation in Japan and analysis 2006/2007. Retrieved June 5, 2007, http://www.jil.go.jp/english/ laborinfo/library/documents/Labor2006_2007.pdf

Kanter, R. M. (1977). Men and women of the corporation. New York: Basic Books.

Kenya National Bureau of Statistics. (2003). 1998/1999 Integrated labour force survey. Nairobi, Kenya: Ministry of Planning and National Development.

Kinyungu, C. (2006). KCPE: Public schools feel the heat. Retrieved January 31, 2007, www.eastandard. net/archives/cl/hm_news/news.php?articleid= 1143963072

Korea National Statistics Office. (2006). Social Statistical Survey. Korea: National Statistics Office.

Kriek, H. J. (2006, May). Personality assessment: Group differences, language proficiency and fairness. Presented at the Society of Industrial and Organizational Psychology Conference, Dallas, TX.

Krings, F., \& Olivares, J. (2007). At the doorstep to employment: Discrimination against immigrants as a function of applicant ethnicity, job type, and raters' prejudice. International Journal of Psychology, 42, 406-417.

Kroeber, A. L. (1937). Caste. In E. R. A. Seligman (Ed.), Encyclopedia of the Social Sciences Vol. 3 (pp. 254 257). New York: Macmillan Company.

Leshem, E. (2004). Israel as a multicultural state at the turn of the twenty-first century. In E. Leshem \& Dorit Roer-Strier (Eds.), Cultural diversity: A challenge to human services (pp. 13-111). Jerusalem: The Hebrew University Magnes Press.

Linacre, S. (2002). National Aboriginal and Torres Strait Islander Social Survey. Canberra, Australia: Australian Bureau of Statistics.

Lüdi, G., \& Werlen, I. (2005). Sprachenlandschaft in der Schweiz [Languages in Switzerland]. Neuchâtel, Switzerland: Federal Statistical Office.

Muchinsky, P. M., Kriek, H. J., \& Schreuder, D. (2003). Personnel psychology. Oxford: Oxford University Press.

Myors, B. (2003). Within-Group Norming: Just Because It's Illegal in America, Doesn't Mean We Can't Do It Here. Paper presented at the $5^{\text {th }}$ Australian Conference on Industrial/Organisational Psychology, Melbourne, Australia.

National Commission for Backward Classes. (2005). Annual report 2003-2004. Retrieved November 13, 2007, http://ncbc.nic.in/html/annual.pdf

National Informatics Centre, India. (2005). Demographic background. Retrieved April 9, 2007, http://india.gov.in/knowindia/population.php

Okkerse, L., \& Termote, A. (2004). How foreign is foreign in the labor market? On foreign laborers in Belgium. Brussels, Belgium: National Institute of Statistics.
Papadopoulou, D. (2005). A study of employment strategies of fragile social groups-Socially margined, individuals with special needs, women and economic immigrants. Athens, Greece: Vocational Training Center of Labour Institute of General Confederation of Greek Workers. Retrieved July 22, 2007, www.inegsee.gr/

Pines, A. M. (2003). Occupational burnout: A crosscultural Jewish-Arab perspective and its implications for career counseling. Career Development International, 8, 97-106.

Rebirth. (2000). Apartheid South Africa: Bantu education. Retrieved August 28, 2007, http://rebirth.co.za/ apartheid_segregation_bantu_education3.htm

Roth, P. L., Bevier, C. A., Bobko, P., Switzer, F. S., \& Tyler, P. (2001). Ethnic group differences in cognitive ability in employment and educational settings: A metaanalysis. Personnel Psychology, 54, 297-330.

SHL. (2006). Validity study V036. Retrieved June 7, 2007, www.shl.co.za

Society for Industrial and Organizational Psychology in South Africa. (2005). Guidelines for the validation and use of assessment procedures for the workplace. Retrieved June 7, 2007, www.siopsa.org.za/

South Africa celebrating diversity. (2007). Retrieved June 7, 2007, www.south-africa.org.za/history

Statistics Bureau, Japan. (2006). Results from 2005 population census [in Japanese]. Retrieved June 5, 2007, www.stat.go.jp/data/kokusei/2005/kekkagai.htm

Steering Committee for the Review of Government Service Provision. (2005). Overcoming indigenous disadvantage: Key indicators 2005. Canberra, Australia: Commonwealth of Australia.

Tavan, C. (2005). Les immigrés en France: une situation qui évolue [Immigrants in France: A situation which evolves]. INSEE Première No. 1042. Paris: INSEE. Retrieved April 15, 2007, www.insee. $\mathrm{fr} / \mathrm{fr} / \mathrm{ffc} /$ docs_ffc/IP1042.pdf

te Nijenhuis, J., de Jong, M., Evers, A., \& van der Flier, H. (2004). Are cognitive differences between immigrant and majority groups diminishing? European Journal of Personality, 18, 405-434.

te Nijenhuis, J., van der Flier, H., \& van Leeuwen, L. (1997). Comparability of personality test scores for immigrants and majority group members: Some Dutch findings. Personality and Individual Differences, 23, 849-859.

te Nijenhuis, J., van der Flier, H., \& van Leeuwen, L. (2003). The use of a test for neuroticism, extraversion, and rigidity for Dutch immigrant job applicants. Applied Psychology: An International Review, 52, 630-647.

Tesser, P. T. M., Merens, J. G. F., \& van Praag, C. S. (1999). Rapportage minderheden 1999 [Report minorities 1999]. Den Haag: Sociaal en Cultureel Planbureau.

U.S. Census Bureau (2004). Projected population of the United States, by Race and Hispanic Origin: 20002050. Retrieved April 9, 2008, www.census.gov/ ipc/www/usinterimproj

van Leest, P. F. (1997). Persoonlijkheidsmeting bij allochtonen [Assessment of personality for ethnic minorities]. Lisse, The Netherlands: Swets \& Zeitlinger.

Zeidner, M. (1986). Are scholastic aptitude tests in Israel biased toward Arab student candidates? Higher Education, 15, 507-522. 